\title{
Patellariaceae revisited
}

\section{Yacharoen $\mathrm{S}^{1,2}$, Tian $\mathrm{Q}^{1,2}$, Chomnunti $\mathrm{P}^{1,2}$, Boonmee $\mathrm{S}^{1}$, Chukeatirote $\mathrm{E}^{2}$, Bhat $\mathrm{JD}^{3}$ and Hyde $\mathrm{KD}^{1,2,4,3^{*}}$}

\author{
${ }^{1}$ Institute of Excellence in Fungal Research, Mae Fah Luang University, Chiang Rai, 57100, Thailand ${ }^{2}$ School of \\ Science, Mae Fah Luang University, Chiang Rai, 57100, Thailand \\ ${ }^{3}$ Formerly at Department of Botany, Goa University, Goa 403 206, India \\ ${ }^{4}$ Key Laboratory for Plant Diversity and Biogeography of East Asia, Kunming Institute of Botany, Chinese Academy of \\ Science, Kunming 650201, Yunnan, China \\ ${ }^{5}$ World Agroforestry Centre, East and Central Asia, Kunming 650201, Yunnan, China
}

Yacharoen S, Tian Q, Chomnunti P, Boonmee S, Chukeatirote E, Bhat JD, Hyde KD 2015 Patellariaceae revisited. Mycosphere 6(3), 290-326, Doi 10.5943/mycosphere/6/3/7

\begin{abstract}
The Dothideomycetes include several genera whose ascomata can be considered as apothecia and thus would be grouped as discomycetes. Most genera are grouped in the family Patellariaceae, but also Agrynnaceae and other families. The Hysteriales include genera having hysterioid ascomata and can be confused with species in Patellariaceae with discoid apothecia if the opening is wide enough. In this study, genera of the family Patellariaceae were re-examined and characterized based on morphological examination. As a result of this study the genera Baggea, Endotryblidium, Holmiella, Hysteropatella, Lecanidiella, Lirellodisca, Murangium, Patellaria, Poetschia, Rhizodiscina, Schrakia, Stratisporella and Tryblidaria are retained in the family Patellariaceae. The genera Banhegyia, Pseudoparodia and Rhytidhysteron are excluded because of differing morphology and/or molecular data.
\end{abstract}

Key words - Apothecia - cup fungi - discomycetes - hysterothecia - Patellaria - Patellariales

\section{Introduction}

The Dothideomycetes is a large class of ascomycetes that are characterised by bitunicate (usually fissitunicate - asci), various types of fruiting bodies and ascospores, and are usually linked to coelomycetous and less rarely hyphomycetous asexual morphs (Hyde et al. 2013). In most cases the fruiting bodies are ascostromata with one or many locules (e.g. Botryosphaeriaceae, Liu et al. 2012) or very small thin-walled ascomata (e.g. Phaeosphaeriaceae, Phookamsak et al. 2014), to large, superficial, thick-walled ascomata (e.g. Halotthiaceae, Zhang et al. 2013) or even stromata (e.g. Shiraiaceae, Liu et al. 2013). There are many other fruiting body forms (e.g., thyriothecia, cleistothecia, Hongsanan et al. 2014).

The Hysteriales have hysterothecoid ascomata, while in some genera (e.g. Rhytidhysteron) the fruiting bodies are apothecial (Fig. 18), however the distinction between these types of fruiting body is not always clear cut. The family Patellariaceae which is characterised by apothecial fruiting bodies was introduced by Corda (1838) with two genera, Cryptodiscus and Mellitiosporium. Since its establishment, members of the family Patellariaceae were moved amongst various taxonomic groups and this was reviewed by Kutorga and Hawksworth (1997) who restudied the family and accommodated 12 genera. Zhang and Hyde (2009) transferred Pseudoparodia to Patellariaceae. 
There have been relatively few molecular studies on members of Patellariaceae (Boehm et al. 2009b, Ruibal et al. 2009, Schoch et al. 2009, Hyde et al. 2013, 2014, Boonmee et al. 2014). Phylogenetic analysis of Rhytidhysteron rufulum (Spreng.) Speg. using a combined LSU, SSU, TEF1 and RPB2 gene dataset showed that the genus grouped into the same clade as other genera in Hysteriaceae (Hysteriales) where it was placed (Hyde et al. 2013). The recent arrangements of genera in Patellariaceae are shown in the Table. 1.

This study re-examines the type species of the genera of Patellariaceae (sensu Lumbsch \& Huhndorf 2010) and provides a morphological account of these genera and suggestions as to where the genera should be placed. Fresh collections and molecular data, however, is required to confirm these placements.

\section{Materials and methods}

\section{Fungal specimens}

Nineteen herbarium specimens examined in this study were representatives of 13 genera in Patellariaceae; they included Baggea, Endotryblidium, Holmiella, Hysteropatella, Lecanidiella, Murangium, Patellaria, Pseudoparodia, Poetschia, Rhizodiscina, Schrakia, Stratisporella and Tryblidaria. These specimens were obtained from the following herbaria: B (Botanischer Garden und Botanisches Museum Berlin-Dahlem, Zentraleinrichtung der Freien Universität Berlin, Germany), BP (Hungarian Natural History Museum), BPI (U.S. National Fungus Collections), CUP-D (Plant Pathology Herbarium, Cornell University), FH (The Harvard University Herbaria and the Botany Libraries), G (Conservatoire et Jardin botaniques de la Ville de Genève), IMI (CABI Bioscience UK Centre), K (Royal Botanical Garden), L (National Herbarium Nederland, Leiden University branch), M (Botanische Staatssammlung München), NY (New York Botanical Garden) and S (Swedish Museum of Natural History). The specimens were then dissected, mounted on slides, and examined under compound microscope (Nikon ECLIPS E80i) fitted with digital camera (Cannon 450D \& 550D). The sizes of various taxonomically important ascogenous features were measured by Tarasoft ${ }^{\circledR}$ Image Frame Work. Figures were composed in Adobe Photoshop CS5 and line drawings are provided when morphological structures are unclear.

\section{Morphological characterization}

Herbarium specimens were rehydrated by $5 \% \mathrm{KOH}$ for 5 minutes. Thin hand sections of ascomata were made by razor blade and mounted on the slides. Lactoglycerol and various dyes (i.e., Melzer's and Cotton blue reagents) were applied to the slide for distinguishing the fungal structural characters (such as an apical ring of the asci: $\mathrm{J}+$ or $\mathrm{J}$-). Cotton blue was used to stain cytoplasm in the cell and Indian-ink was used to show appendages or mucilaginous sheaths. Other distinct structures were observed including as ascomata shape and size, the presence or absence of pseudoparaphyses, and shape and size of asci and ascospores.

\section{Results and Discussion}

Hyde et al. (2013) provided a backbone tree to Dothideomycetes based on combined dataset of LSU, SSU, TEF1 and RPB2 sequences. Phylogenetically, the placement of Patellariaceae (Patellariales) is close to Tubeufiaceae; this also concurs with Boonmee et al. (2014). A similar result was obtained by Wijayawardene et al. (2014), although Tubeufiaceae and Wiesneriomycetidae made up Tubeufiales with strong support. In all cases the support for separation of Tubeufiales and Patellariales in the backbone tree had low support, but the genera in these orders clustered with high support, indicating that they are distinct orders. This is probably because the tree is not yet well-populated. The two genera of Patellariaceae that presently have sequence data cluster together with strong support (95/1.00) in Boonmee et al. (2014). Rhytidhysteron does not cluster in Patellariaceae, and is aligned in the same clade with Hysteriaceae in Hysteriales (Boehm et al. 2009b, Schoch et al. 2009, Hyde et al. 2013). 
Table 1 Recent revisions of Patellariaceae.

\begin{tabular}{lll}
\hline \multicolumn{1}{c}{$\begin{array}{c}\text { Kutorga and Hawksworth } \\
\text { (1997) }\end{array}$} & \multicolumn{1}{c}{$\begin{array}{c}\text { Lumbsch and Huhndorf } \\
(\mathbf{2 0 1 0})\end{array}$} & \multicolumn{1}{c}{ This study } \\
\hline Baggea & Baggea & Baggea $^{\#}$ \\
Banhegyia & Banhegyia & Endotryblidium $^{\#}$ \\
Holmiella & ?Endotryblidium & Holmiella $^{\#}$ \\
Lecanidiella & Holmiella & Hysteropatella $^{\#}$ \\
Murangium & Lecanidiella & Lecanidiella $^{\#}$ \\
Patellaria & Lirellodisca & Lirellodisca $^{\#}$ \\
Poetschia & Murangium & Murangium $^{\#}$ \\
Rhizodiscina & Patellaria & Patellaria $^{\#}$ \\
Rhytidhysteron & Poetschia & Poetschia $^{\#}$ \\
Scharkia & Pseudoparodia & Rhizodiscina $^{\#}$ \\
Stratisporella & Rhizodiscina & Schrakia $^{\#}$ \\
Tryblidaria & Rhytidhysteron & Stratisporella $^{\#}$ \\
& Schrakia & Tryblidaria $^{\#}$ \\
& Stratisporella & \\
\hline
\end{tabular}

\# = no sequence for this genus in GenBank

In this study, we accept 14 genera in Patellariaceae which are described and illustrated. The genus Patellaria as it stands is clearly a monophyletic clade in the Class Dothideomycetes (Boehm et al. 2009b, Ruibal et al. 2009, Schoch et al. 2009, Suetrong et al. 2009, Hyde et al. 2013). However, a natural classification of Patellariaceae will not be possible until all genera are recollected and sequenced. Banhegyia was transferred to Mycomelaspilea (Melaspileaceae, Arthoniomycetes) based on flagellate ascospores in Banhegyia, which is similar to Mycomelaspilea (current name is Melaspilea proximella (Nyl.) Nyl., Sanderson et al. 2009), and this is followed here. Rhytidhysteron is placed in the family Hysteriaceae based on molecular evidence (Hyde et al. 2013).

As the family Patellariaceae comprises apothecial ascomycetes which are unlike most other Dothideomycetes we detail their main features below. Many details come from Kutorga \& Hawksworth (1997).

Apothecia are mostly superficial, slightly immersed at beginning or rarely erumpent, solitary, scattered or in small aggregated groups, uniloculate, closed when young, opened at maturity, subglobose to globose, disc flattened or deeply cup-shaped, or convex, somewhat ellipsoid, with longitudinal or rounded opening, often folding at the rim, center, smooth, rough or zigzagged, thick or velvet in the middle, mostly black (Fig.1).

Anchoring hyphae (vegetative hyphae) are branched, septate, brown to dark brown, connecting apothecia with host surface.

Exciple (peridium) mostly comprising 2 layers, outer layer thicker than inner layer, pseudoparenchyma were formed, conjugated on host surface at the base, isodiametric cells or rarely of elongated and radiating cells (Fig.1), outer layer dense, compact with pigmented cells, usually binding with lighter inner layer which were, indistinct in some genera.

Hypothecium (layer for which asci originate) or subhymenium, binding to exciple layer, inverted conically, merged with the host surface at the base, compressed, being pseudoparenchymatous, rarely prosenchymatous, slightly varied in thickness, hyaline (Fig.1).

Hamathecium (sterilized tissue) always originating between asci, continuing growth in same direction as asci, pseudoparaphyses always present, erected or branched, septate or aseptate, slightly swollen on the apex, usually anastomosing and forming a dark brown or black epithecium over the asci (Fig. 3, in Kutorga and Hawksworth 1997).

Asci reproductive hyphae, originated on hypothecium layer, growth parallel with hamathecium, 8-spored, rarely for 4-6-spored, bitunicate, fissitunicate in some genera, cylindrical to oblong, clavate, broad in the middle, narrowed at the stipe with or without a pedicel. 


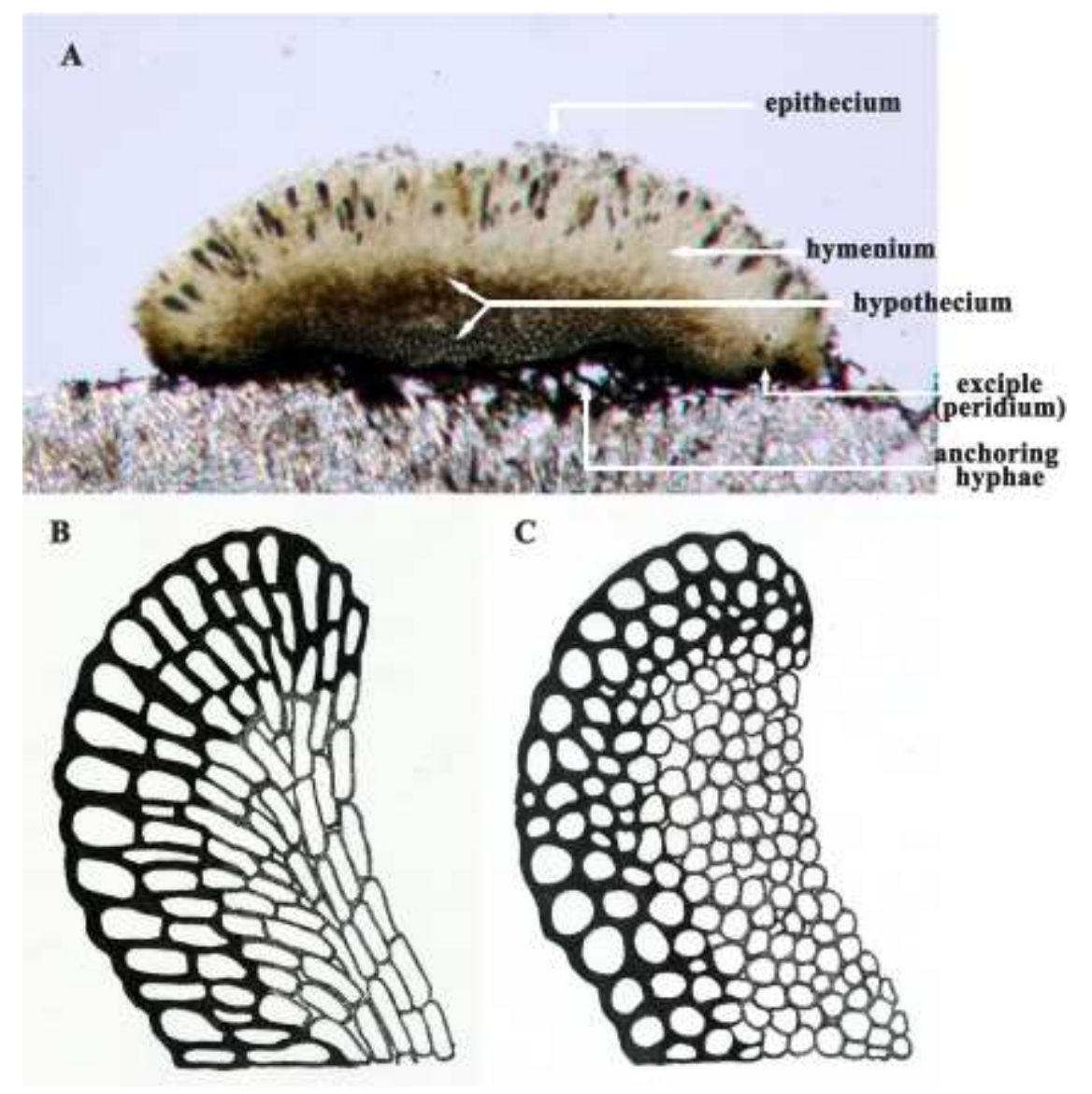

Fig. 1 - Exciple tissue type (Redrawn from Kutorga and Hawksworth, 1997). (A) Vertical section of an ascoma in Patellariaceae. (B) Iso-radiating cells (comprising textura prismatica, prosenchyma). (C) Iso-diametric cells (comprised of textura globulosa-angularis).

Ascospores varying in shape, such as obovoid or clavate or elliptic to oblong, mostly constricted at the septa, rounded at both ends, 1-3-septate, some muriform or euseptate was, hyaline or brown to dark brown. Asexual morphs barely known. Holmiella sabina has a Corniculariella asexual morph.

A description is given only for the species in this treatment, when the genus in monotypic.

\section{Taxonomy}

Patellariaceae Corda, Icon. fung. (Prague) 2: 37 (1838)

= Lecanidiaceae O.E. Erikss., Op. bot. Soc. bot. Lund 60: 78 (1981)

Facesoffungi number: FoF 00342

Saprobic on dead wood in terrestrial habitats, possibly lichenicolous in some genera. Sexual morph: Ascomata apothecia or hysterothecia-like, superficial, closed when young and opening to expose the epithecium at maturity, without stalk or foot, cupulate, discoid or cylindrical, sometimes with rolled margins, dark-coloured, with carbonized cells. Exciple pseudoparenchymatous, thickwalled, with dark brown isodiametric cells at the outer layers and pale to light brown cells at inner wall and basal cell layers. Hypothecium pseudoparenchymatous or prosenchymatous. Hamathecium composed of paraphysoids or paraphyses, forming an epithecium, J+ or J-. Asci 8-spored, bitunicate, fissitunicate, cylindrical to clavate, pedicellate, apically rounded with an ocular chamber, J+ or J-. Ascospores 2-3-seriate overlapping, varying in shape (i.e. obovoid or clavate to oblong), euseptate or distoseptate, in latter cells with reduced cell-lumen, 1-6-septate, occasionally muriform, hyaline or light brown. Asexual morph: See under notes. 
Type genus: Patellaria Fr.

Notes: Holmiella sabina has a Corniculariella asexual morph. Wijayawardene et al. (2012) stated that Rhytidhysteron has "Aposphaeria"-like and "Diplodia"-like asexual morphs. However Rhytidhysteron belongs in Hysteriaceae which is unrelated to Patellariaceae.

\section{Key to genera of Patellariaceae}

1. Ascomata clearly hysterothecium-like

1. Ascomata hysterothecial to apothecial

2. Ascospores hyaline, surrounded by sheath Hysteropeltella

2. Ascospores coloured, lacking a sheath Hysteropatella

3. Apothecium immersed or erumpent . .4

3. Apothecium superficial. .5

4. Asci cylindrical, ascospores uni-seriate, verrucose, lichenicolous

Stratisporella

4. Asci broadly clavate, 3-4-seriate, smooth-walled, not growing on lichens... Endotryblidium

5. Asci with more than 8 spores. Baggea

5. Asci with 8 or less spores. 6

6. Ascospores muriform. 7

6. Ascospores with transverse-septate. 8

7. Ascospores hyaline

7. Ascospore brown Tryblidaria

8. Ascospores euseptate. Murangium

8. Ascospores distoseptate

9. Ascospores 1-septate

9. Ascospores with more than 1-septate

10. Ascospores with appendages

10. Ascospores without appendages

11. Ascospores shorter than $15 \mu \mathrm{m}$

11. Ascospores longer than $15 \mu \mathrm{m}$

12. Apothecia reddish-brown.

12. Apothecia dark brown

13. Ascospores 3-septate

13. Ascospores with more than 3-septate Lirellodisca .10 13 Holmiella . .11 12

\section{9}

11

Rhizodiscina

Schrakia

Poetschia

Lecanidiella

Patellaria

Patellaria Fr., Syst. mycol. (Lundae) 2(1): 158 (1822)

Facesoffungi number: FoF 00343

Saprobic on dead wood, stems or rotten paper in terrestrial habitats. Sexual morph: Ascomata apothecial, superficial, scattered, sessile, closed at first and opening at maturity, longitudinally wide, exposing the dark hymenium at the center, circular, flattened, with a carbonaceous rim, black. Exciple 2-layered, outer layer pseudoparenchymatous, black, inner layer composed of thick-walled, cells of textura prismatica, gelatinous, blue-black at the base (hypothecium) where cells are of textura angularis, green-blue to colourless. Hamathecium composed of 1.5-3 $\mu \mathrm{m}$ wide, cylindrical, hyaline, septate, branched paraphyses, slightly swollen and rounded at the apex, forming a dark and thick epithecium over the asci. Asci 8-spored, bitunicate, fissitunicate, cylindrical, clavate, short and slightly curved pedicel, apically rounded, with an ocular chamber. Ascospores 2-3-seriate overlapping, clavate to fusiform, trans-septate, hyaline. Asexual morph: Unknown.

Notes: The main characters of this genus are superficial, black, apothecioid ascomata, with a greenish-black epithecium formed from the branched and swollen paraphyses, bitunicate, fissitunicate asci, and hyaline, clavate to cylindrical, phragmo-septate ascospores (Kutorga and Hawksworth 1997). There are variations in number of asci, spore size, and number of ascospores within the asci. The importance of these taxonomic criteria needs to be established. Sequence data is only available for Patellaria atrata (Boehm et al. 2009a, 2009b, Schoch et al. 2009, Suetrong \& Jones 2006, Suetrong et al. 2009). 
Ten species were accommodated in the genus Patellaria by Hawksworth et al. (1995), while Butler (1940) reported five species. However, Dennis (1964, 1978) transferred Patellaria clavispora Berk. \& Broom. to Patellatopsis. Dennis (1954) reported four species from the West Indies which included a new species, Patellaria jamaicensis Dennis. Seven species were reported from India (Tilak \& Srinivasulu 1974). P. schwarzmanniana Kazhieva (Kazhieva 1974) and P. desertorum Kravtzev (Kravtzev 1955) were also recorded from Kazakhstan. Presently, reassessment of the large number of species are needed to delimit the circumscription of the genus.

Type species: Patellaria atrata (Hedw.) Fr., Syst. mycol. (Lundae) 2(1): 158 (1822)

Fig. 2

ELichen atratus Hedw., Descr. micr.-anal. musc. frond. 2(3): 61 (1788) [1789]

Facesoffungi number: FoF 00344

Saprobic on dead wood, stems or rotten paper in terrestrial habitats. Sexual morph: Ascomata 675-1160 × 220-300 $\mu \mathrm{m}$, apothecial, superficial, scattered, sessile, closed at first and opening at maturity, longitudinally wide, exposing the dark hymenium at the center, circular, flattened, with a carbonaceous rim, black. Exciple 45-76 $\mu \mathrm{m}$ wide $(\bar{x}=65 \mu \mathrm{m} ; \mathrm{n}=10)$, 2-layered, outer layer pseudoparenchymatous, black, inner layer composed of thick-walled cells of textura prismatica, gelatinous, blue-black at the base (hypothecium) with cells of textura angularis, green blue to colourless. Hamathecium composed of 1.5-3 $\mu \mathrm{m}$ wide, thick, cylindrical, hyaline, septate, branched paraphyses, slightly swollen and rounded at the apex, forming a dark and thick epithecium over the asci. Asci $98-135 \times 15-30 \mu \mathrm{m}(\bar{x}=120 \times 20 \mu \mathrm{m} ; \mathrm{n}=10)$, 8-spored, bitunicate to fissitunicate, cylindrical, clavate, with a short and slightly curved pedicel, apically rounded, with an ocular chamber. Ascospores 30-45 × 7-10 $\mu \mathrm{m}(\bar{x}=37 \times 9 \mu \mathrm{m} ; \mathrm{n}=10), 2-3$-seriate overlapping, clavate to fusiform, slightly curved, narrowed at the lower end, 5-11-septate, hyaline. Asexual morph: Unknown.

Material examined: USA, South Dakota, Northville, on wood of Acer negundo L. (Sapindaceae), October 1925, J.F. Brenckle (Petrak Myc. g. exs 1556, IMI 32777).

Notes: This saprotrophic fungus preferentially colonizes exposed phloem fibers of wood and the decay mode was reported to resemble white rot (Unterseher et al. 2003). This would be unusual for an ascomycete species which are usually soft rotting fungi. We were unable to loan the holotype from L due to their herbarium loan policy and thus illustrate a specimen from IMI identified by F. Petrak.

Baggea Auersw., Hedwigia 5: 1 (1866)

Facesoffungi number: FoF 00345

Notes: Auerswald (1866) introduced Baggea as a monotypic genus in Hysteriaceae and this was accepted by Saccardo (1883) and Rehm (1912). Nannfeldt (1932) and Zogg (1962) re-studied the genus and, based on the characteristics of the ascomata and pseudoparaphyses, moved this to Lecanorales. Rehm (1896), Clements and Shear (1931) and von Arx and Müller (1975) assigned the genus to the Patellariaceae. There is no report concerning cultures or sequence data for this genus. The fruiting bodies of this genus are interesting as they are apothecial or hysterothecia-like depending on which terminology one adopts and are thus typical of Patellariales. Baggea is however, unusual in having polysporous asci and allantoid ascospores that differ from other genera in Patellariaceae. Baggea seems to be a likely member of Patellariaceae but it needs to be recollected and sequenced.

Type species: Baggea pachyascus Auersw., Hedwigia 5: 1 (1866)

Fig. 3

Facesoffungi number: FoF 00346

Saprobic on dead branches of Quercus sp. in terrestrial habitats. Sexual morph: Ascomata 175-250 × 150-205 $\mu \mathrm{m}$, apothecial or hypothecia-like, superficial, fusiform to ellipsoidal, narrow at the base, circular, triangular or irregular in shape when wet, black, coriaceous, opening by a longitudinal slit or radial ruptures, exposing blackish discs, with margin slightly raised above flat and black slit, which widens on wetting. Exciple $23-54 \mu \mathrm{m}$ wide $(\bar{x}=38 \mu \mathrm{m} ; \mathrm{n}=10)$, 

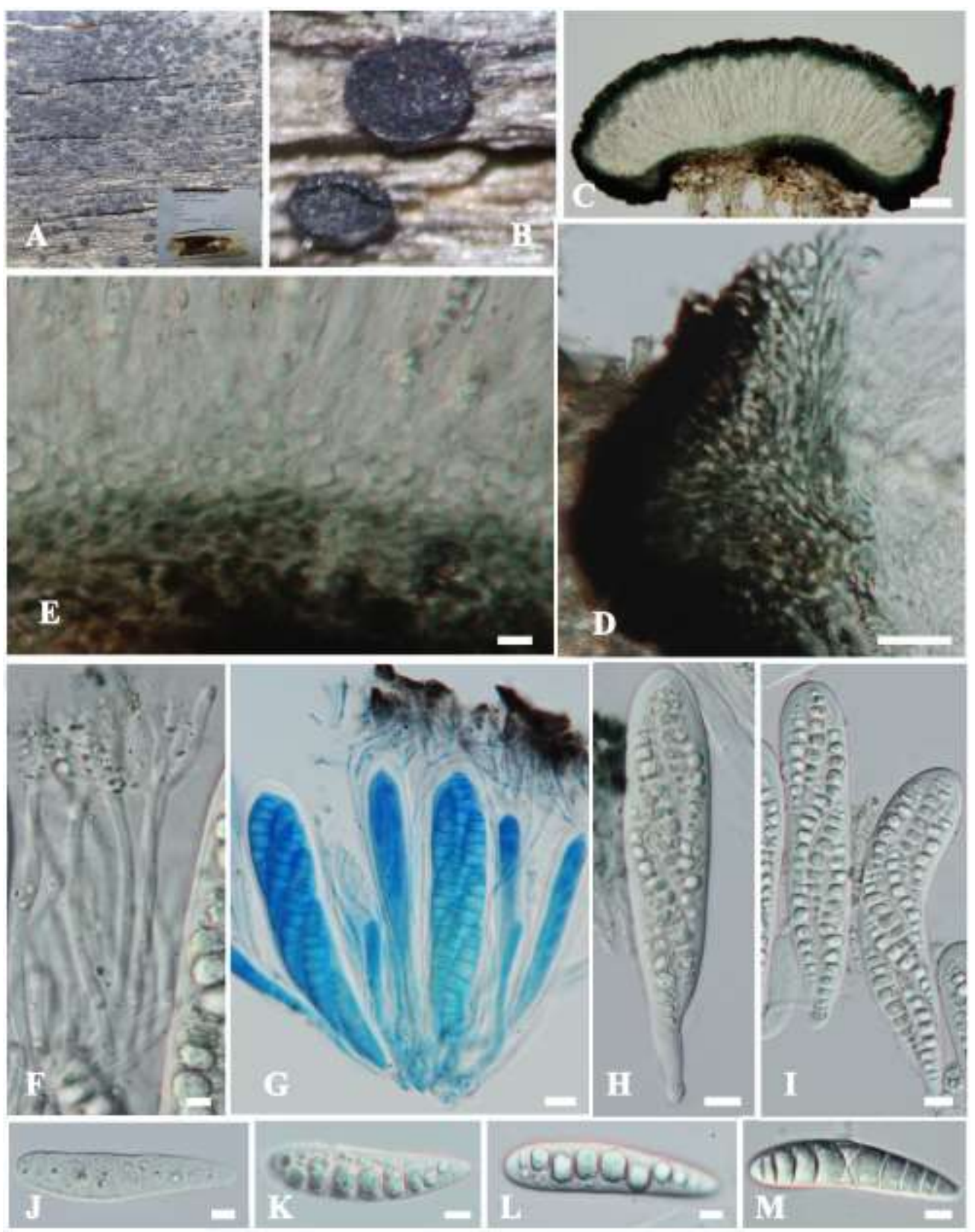

Fig. 2 - Patellaria atrata (IMI 32777). (A, B) Apothecia on host tissue. (C) Hand section of apothecium. (D) Peridium with elongated and rounded cells. (E) Hypothecium with textura angularis tissue. (F) Hamathecial tissue; note pseudoparapahyses branching at the ends. (G) Young and mature asci showing ocular chamber in cotton blue. (H, I) Mature asci with 8-spored. (J-M) Ascospores. Scale bars: $C=50 \mu \mathrm{m}, D, G-I=10 \mu \mathrm{m}, E=20 \mu \mathrm{m}, F, J-M=5 \mu \mathrm{m}$.

pseudoparenchymatous, composed of an outer wall of black to dark brown cells and inner wall of paler brown cells arranged in a textura globulosa. Hamathecium comprising relatively wide, 3-5 $\mu \mathrm{m}$ wide $(\bar{x}=4 \mu \mathrm{m} ; \mathrm{n}=10)$, septate, branched, pseudoparaphyses, especially in upper part, occasionally anastomosed in the lower part, hyaline, with tips slightly swollen and agglutinated, forming a light brown surface layer (epithecium). Asci 99-144 $\times 29-51 \mu \mathrm{m}(\bar{x}=122 \times 41 \mu \mathrm{m} ; \mathrm{n}=$ $10)$, polysporous, bitunicate, broadly clavate or clavate, with apical dome and short pedicel, wall 1$2 \mu \mathrm{m}(\mathrm{n}=10)$ thick, ocular chamber not obvious in mature specimens, J-. Ascospores $12-15 \times 2-4$ $\mu \mathrm{m}(\bar{x}=13 \times 3 \mu \mathrm{m} ; \mathrm{n}=10)$, numerous, allantoid, with rounded ends, usually with 3 -transverse septa, occasionally up to 6 septa, curved, thin-walled, brown, smooth-walled. Asexual morph: Unknown. 
Table 2 Size synopsis of specimens identified as Rhytidhysteron brasiliense in Thailand

\begin{tabular}{|c|c|c|c|c|c|}
\hline Location & Host & Specimen & $\begin{array}{c}\text { Apothecia } \\
(\mu \mathrm{m})\end{array}$ & $\begin{array}{l}\text { Asci } \\
(\mu \mathrm{m})\end{array}$ & $\begin{array}{c}\text { Ascospore } \\
(\mu \mathrm{m})\end{array}$ \\
\hline Phitsanulok & Dead wood & $\begin{array}{c}\text { MFLUCC } \\
12-0530\end{array}$ & $\begin{array}{c}1,087-1,715 \times \\
340-447\end{array}$ & $\begin{array}{c}220-247 \times \\
12-13\end{array}$ & $\begin{array}{c}29-43.5 \times \\
10-14\end{array}$ \\
\hline Chiang Mai & Dead wood & $\begin{array}{c}\text { MFLUCC } \\
12-0529\end{array}$ & $\begin{array}{c}195-227 \times \\
58-82\end{array}$ & $\begin{array}{c}80-105 \times \\
11-16\end{array}$ & $\begin{array}{c}27-32 \times \\
9-13\end{array}$ \\
\hline Chiang Mai & Dead wood & $\begin{array}{l}\text { MFLUCC } \\
12-0528\end{array}$ & $\begin{array}{c}155-195 \times \\
58-81\end{array}$ & $\begin{array}{c}107-90 \times \\
9-11\end{array}$ & $\begin{array}{c}27-35 \times \\
9-10\end{array}$ \\
\hline Phayao & Dead wood & $\begin{array}{c}\text { MFLUCC } \\
12-0013\end{array}$ & $\begin{array}{c}1,370-1,465 \times \\
815-880\end{array}$ & $\begin{array}{c}130-150 \times \\
10-13\end{array}$ & $\begin{array}{c}30-38 \times \\
12-17\end{array}$ \\
\hline Chiang Rai & $\begin{array}{c}\text { Dead branch of } \\
\text { Dimocarpus longan }\end{array}$ & $\begin{array}{c}\text { MFLUCC } \\
12-0567\end{array}$ & $\begin{array}{c}182-195 \times \\
70-98\end{array}$ & $\begin{array}{l}90-107 \times \\
9-11\end{array}$ & $\begin{array}{c}27-35 \times \\
9-11\end{array}$ \\
\hline Phayao & Dead wood & $\begin{array}{c}\text { MFLUCC } \\
12-0011\end{array}$ & $\begin{array}{l}443-562 \times \\
360-515\end{array}$ & $\begin{array}{l}320-410 \times \\
8-11\end{array}$ & $\begin{array}{c}34-42 \times \\
11-17\end{array}$ \\
\hline Chiang Rai & Dead wood & $\begin{array}{c}\text { MFLUCC } \\
12-0569\end{array}$ & $\begin{array}{c}196-212 \times \\
58-82\end{array}$ & $\begin{array}{c}80-105 \times \\
11-16\end{array}$ & $\begin{array}{c}28-32 \times \\
9-13\end{array}$ \\
\hline
\end{tabular}

Material examined: GERMANY, Bavaria, Windsheim, on dead branch of Quercus sp. (Fagaceae), 1874, H. Rehm (B 700014160).

Notes: The holotype and isotype specimens collected by D. Bagge were presumed lost and Kutorga \& Hawksworth (1997) designated Rehm's collection (GERMANY, Franken, in Sugenhium forest, on young Eichaestchen, 1869, Rehm No. 28) as neotype. We examined a specimen listed in Kutorga \& Hawksworth (1997). A new variety, Baggea pachyascus var. macrospora Magnes et al. (1998) was also introduced, however, Index Fungorum (2014) place both varieties in synonymy with Baggea pachyascus.

Endotryblidium Petr., Sydowia 13(1-6): 244 (1959), MycoBank: 1812

Facesoffungi number: FoF 00347

Notes: Endotryblidium was introduced by Petrak (1959) with a single species (E. insculptum) characterized by apothecia aggregated on the host, a pseudoparenchymatous peridium, 4-6-, rarely 8 -spored, short pedicellate, clavate asci, numerous filamentous paraphyses and oblong to ellipsoidal ascospores. In our study it was found that the hypothecium comprises numerous, slightly broad pseudoparaphyses and mostly 8-spored, bitunicate asci. The genus has not been well-studied. We place Endotryblidium in Patellariaceae based our observations on morphological characters which match the family.

Type species: Endotryblidium insculptum (Cooke) Petr., Sydowia 13(1-6): 245 (1959) Fig. 4

$\equiv$ Triblidium insculptum Cooke [as 'Tryblidium'], Grevillea 4(no. 32): 182 (1876)

= Brunaudia insculpta (Cooke) Kuntze [as 'Bruneaudia'], Revis. gen. pl. (Leipzig) 3(2): 447 (1898)

Facesoffungi number: FoF 00348

Saprobic on bark of dead branches of hickory in terrestrial habitats. Sexual morph: Ascomata 450-930 × 200-390 $\mu \mathrm{m}$, apothecial, scattered, solitary, immersed, erumpent, irregular, pseudoparenchymatous, black. Exciple $90-145 \mu \mathrm{m}(\bar{x}=120 \mu \mathrm{m} ; \mathrm{n}=10)$ wide, with carbonaceous, dark brown to black, pseudoparenchymatous cells. Hamathecium composed of $2-3.5 \mu \mathrm{m}(\bar{x}=3$ $\mu \mathrm{m} ; \mathrm{n}=10$ ), cylindrical, elongated, branched, hyaline, septate, pseudoparaphyses, slightly swollen at the apex, embedded in gelatinous matrix, anastomosing to form a black epithecium above the asci. Asci 100-120 × 40-60 $\mu \mathrm{m}(\bar{x}=115 \times 50 \mu \mathrm{m} ; \mathrm{n}=10), 8$-spored, bitunicate, broadly clavate, with a short pedicel at the base, slightly narrow at the apex, with a distinct ocular chamber. Ascospores 50-60 $\times 20-30 \mu \mathrm{m}(\bar{x}=50 \times 25 \mu \mathrm{m} ; \mathrm{n}=10)$, overlapping and irregular arranged, broadly ellipsoid to oblong, broader at the upper part, asymmetrically 1-septate, constricted at the septa, rounded at the ends, light brown to brown, surrounded by a mucilaginous sheath. Asexual morph: Unknown. 


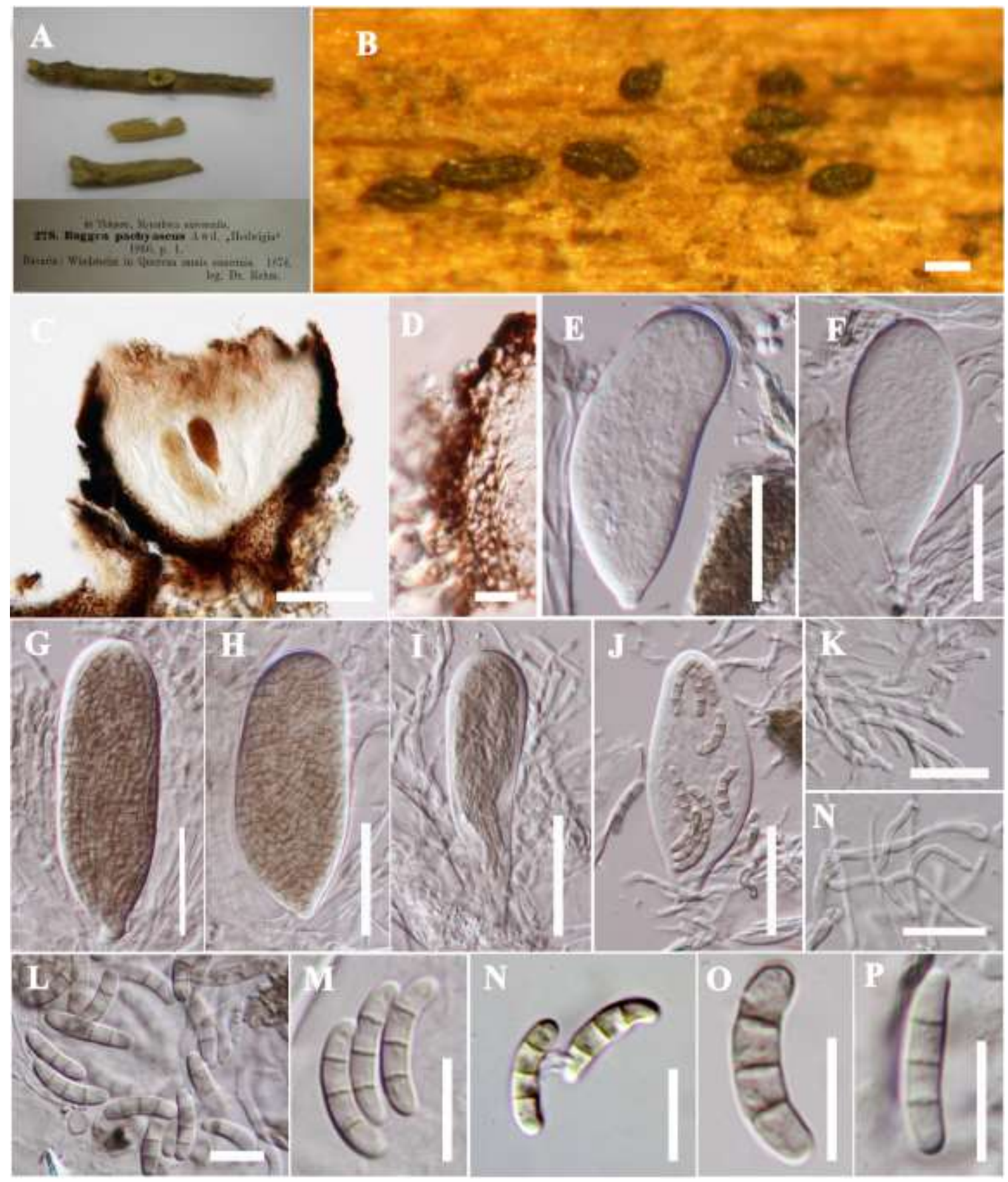

Fig. 3 - Baggea pachyascus (B 700014160). (A) Herbarium specimen. (B) Appearance of apothecia on host tissue. (C) Vertical section of hysterothecium. (D) Exciple. (E-J) Polysporous asci. (K-L) Hamathecium with hyaline branched pseudoparaphyses. (M-Q) Light brown, allantoid ascospores with trans-septate. Scale bars: $B, M-P=10 \mu \mathrm{m}, C-L=20 \mu \mathrm{m}$.

Material examined: USA, New Jersey, Newfield; on dead branches of hickory (Carya sp., Juglandaceae), May 1874, Ellis (K(M) 2111, holotype)

Holmiella Petrini, Samuels \& E. Müll., Ber. schweiz. bot. Ges. 89(1-2): 83 (1979)

Possible synonym:

Caldesia Rehm, in Winter, Rabenh. Krypt.-Fl., Edn 2 (Leipzig) 1.3(lief. 32): 289 (1888) [1896]

Facesoffungi number: FoF 00349 
Saprobic in terrestrial habitats. Sexual morph: Ascomata apothecial, solitary, superficial, exposing a velvet hymenium when mature, globose, black. Exciple pseudoparenchymatous, with outer layer composed of dark brown to black, slightly cracking, thick-walled cells of textura globulosa-angularis, with inner layer composed of thin, light brown cells of textura of epidermoidea-like. Hamathecium composed of 1-2 $\mu \mathrm{m}$ wide, filamentous, septate, branched, hyaline, anastomosing pseudoparaphyses, forming a dark brown epithecium above the asci. Asci 8spored, bitunicate, clavate, short pedicellate, broad at the apex, with a wide ocular chamber. Ascospores 2-seriate overlapping, clavate to ellipsoidal, 1-septate, cell wall with 2-layers, with germ pores at both ends, brown. Asexual morph: Corniculariella-like.

Notes: The genus Holmiella was introduced to accommodate Triblidium sabinum De. Not. (Petrini et al. 1979) described by De Notaris (1867) from Juniperus (Pirozynski \& Reid 1966). In this study, the holotype specimen was not available for loan. Eutryblidiella sabina, the collection from Pakistan (IMI 177087, current name is H. sabina) was selected for examination and follows Kutorga \& Hawksworth (1997) and this decision was also corresponded in a discussion by Pirozynski \& Reid (1966).

Type species: Holmiella sabina (De Not.) Petrini, Samuels \& E. Müll., Ber. schweiz. bot. Ges. 89(1-2): 84 (1979)

$\equiv$ Triblidium sabinum De Not. [as 'Tryblidium'], Comm. Soc. crittog. Ital. 2(3): 491 (1867)

= Karschia sabina (de Not) Hedwigia 21: 1151882

= Cenangium deformatum Peck, Bull. N. Y. State Museum 28: 68. 1876

Facesoffungi number: FoF 00350

Saprobic on bark of Juniperrus macropoda in terrestrial habitats. Sexual morph: Ascomata $365 \times 675 \mu \mathrm{m}$, apothecial, solitary, superficial, exposing a velvet hymenium when mature, globose, black. Exciple 22-58 $\mu \mathrm{m}$ wide, $(\bar{x}=42 \mu \mathrm{m} ; \mathrm{n}=10)$, pseudoparenchymatous, with outer layer composed with dark brown to black, slightly cracking, thick-walled cells of textura globulosaangularis, with inner layer composed with thin, light brown cells of textura epidermoidea. Hamathecium composed of 1-2 $\mu \mathrm{m}$ wide, filamentous, septate, branched, hyaline, anastomosing pseudoparaphyses, forming a dark brown epithecium above the asci. Asci 30-37 × 115-135 $\mu \mathrm{m}(\bar{x}$ $=34 \times 128 \mu \mathrm{m} ; \mathrm{n}=10), 8$-spored, bitunicate, clavate, short pedicellate, broad at the apex, with a thick ocular chamber. Ascospores 33-40 $\times 17-20 \mu \mathrm{m}(\bar{x}=18 \times 37 \mu \mathrm{m} ; \mathrm{n}=10)$, 2-seriate overlapping, clavate to ellipsoidal, aseptate, constricted at septa, cell wall with 2-layers, upper cell slightly wider than lower cell, without a mucilaginous sheath, with germ pores at both ends, brown, smooth-walled. Asexual morph: Corniculariella-like.

Material examined: PAKISTAN, Quetta, Ziarat, on bark of Juniperus macropoda Boiss. (Cupressaceae), 23 September 1969, Tarig Mahmood (IMI 177087).

Hysteropatella Rehm., in Winter, Rabenh. Krypt.-Fl., Edn 2 (Leipzig) 1.3(lief. 33): 367 (1890) [1896]

Facesoffungi number: FOF 381

Notes: The genus Hysteropatella was introduced by Rehm (1890), based on Hysterium prostii. Zogg (1962) accepted Farlowiella, Gloniella, Gloniopsis, Glonium, Hysterium, Hysterocarina and Hysterographium in Hysteriaceae and Eriksson (2006) tentatively included Hysteroglonium, Hysteropatella and Pseudoscypha. Schoch et al. (2009) analyzed the available sequence data for Hysteropatella and showed that H. clavispora (Peck) Höhn. and H. elliptica (Fr.) Rehm were related to Patellaria atrata forming a distinct clade within the Pleosporomycetidae; this was postulated to represent Patellariales. Thus, Hysteropatella is not included in the Hysteriaceae; it clusters in the family Patellariaceae (Hyde et al. 2013).

Type species: Hysteropatella prostii (Duby) Rehm., in Winter, Rabenh. Krypt.-Fl., Edn 2 (Leipzig) 1.3(lief.33):367(1890)[1896], 

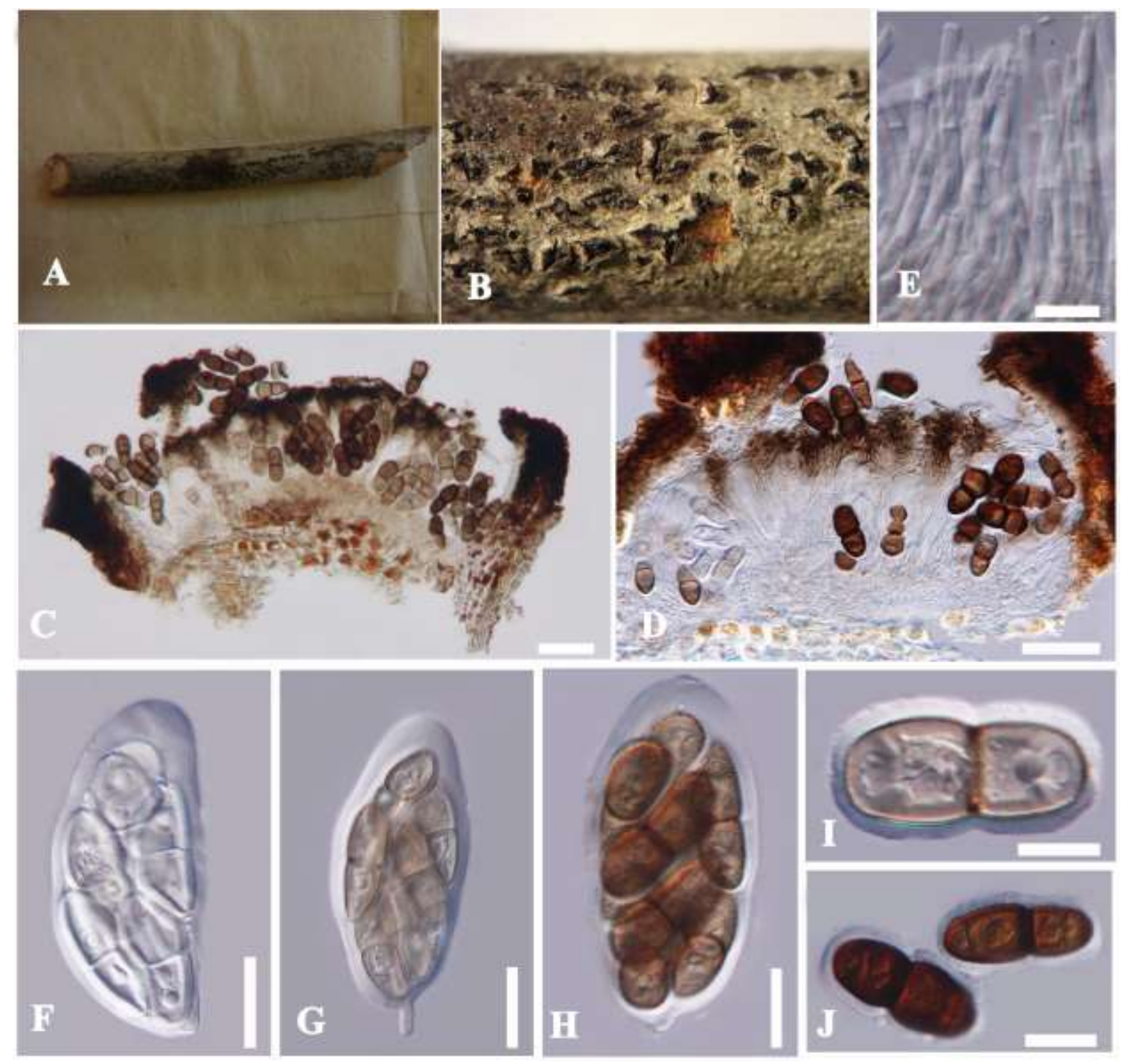

Fig. 4 - Endotryblidium insculptum (K(M) 2111, holotype). (A) Herbarium specimen. (B) Ascomata on host surface. (C) Cross section of ascoma with carbonaceous cell of peridium. (D) Epithecium formed above the asci. (E) Elongate pseudoparaphyses with septa. (F-H) Young and mature asci with short pedicels. (I, J) Ascospores with 1-septate surrounded by a mucilaginous sheath. Scale bars: $C-D=100 \mu \mathrm{m}, E-H=20 \mu \mathrm{m}, I-J=10 \mu \mathrm{m}$.

Saprobic on bark of Malus domestica, rarely on Prunus sp. and Pyrus communis in terrestrial habitats. Sexual morph: Ascomata 267-916 × 121-340 $\mu \mathrm{m}$, hysterothecial, gregarious, erumpent to superficial, persistent dark, carbonaceous, boat-shaped with longitudinal slit. Exciple 17.5-37.5 $\mu \mathrm{m}$ wide, 2-layers, composed of small pseudoparenchymatous cells, the outer layer heavily encrusted with pigments and the inner layer distinctly thin-walled, pallid and compressed. Hamathecium comprising cellular, cylindrical, branched pseudoparaphyses, embedded in a gelatinous matrix, darkened at the apex at maturity, forming a dark epithecium over the asci. Asci 40-82 $\times 10-15 \mu \mathrm{m}$ $(\bar{x}=60 \times 10 \mu \mathrm{m} ; \mathrm{n}=10), 8$-spored, bitunicate, cylindrical to clavate, pedicellate, slightly swollen at the apex. Ascospores 14-22 $\times 5-7 \mu \mathrm{m}(\bar{x}=17 \times 6 \mu \mathrm{m} ; \mathrm{n}=10), 2$-seriate overlapping, reniform to ellipsoid or fusoid, phragmosporous, 3 -septate at maturity, constricted at the septa, occasionally surrounded by a sheath, and often show bipolar asymmetry, ranging from hyaline to dark brown. Asexual morph: Unknown. 

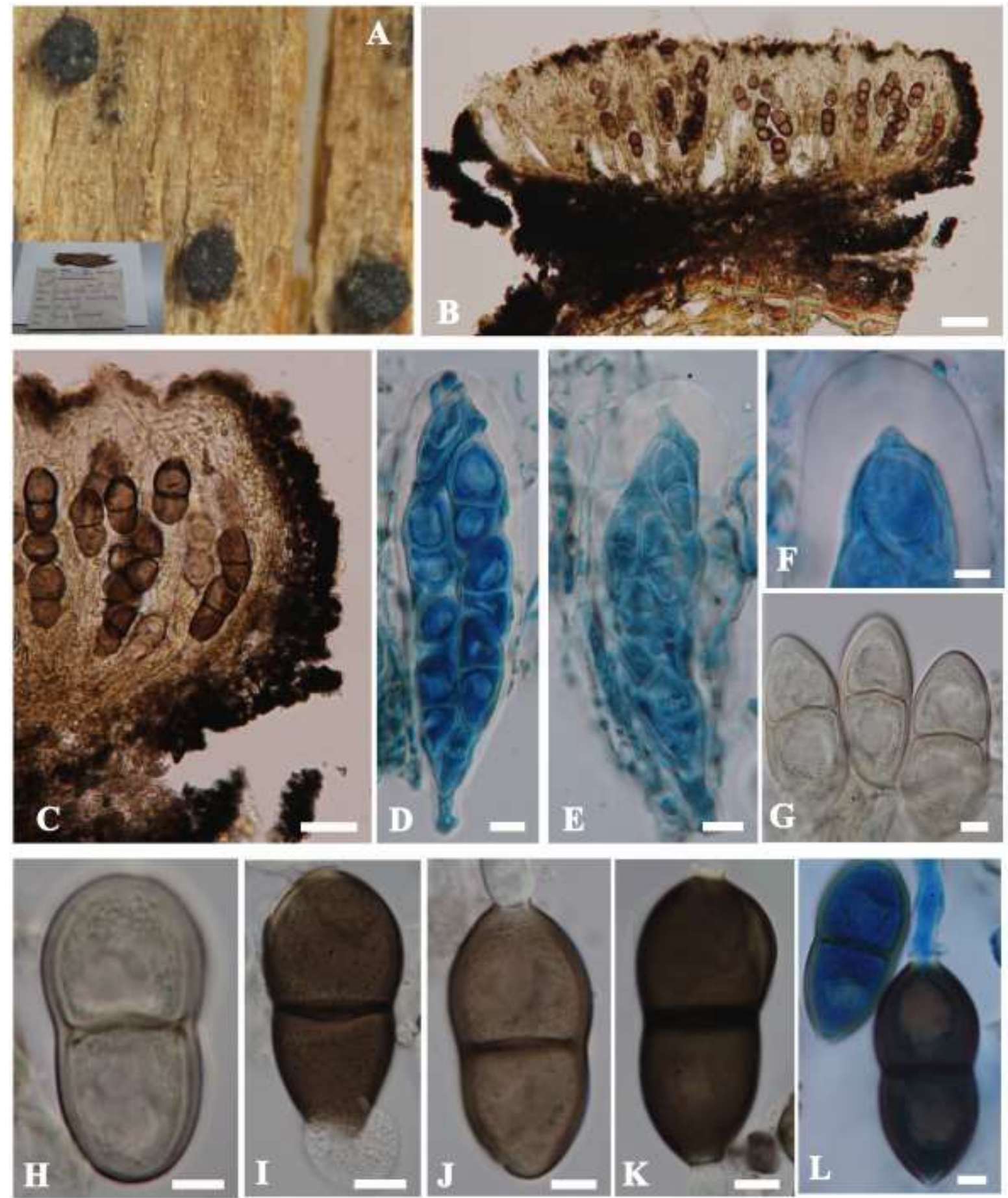

Fig. 5 - Holmiella sabina (IMI 177087). (A) Apothecia on bark. (B) Vertical section of apothecium. (C) Peridium. (D, E) Young bitunicate asci with pseudoparaphyses. (F) Ocular chamber after application of cotton blue. (G-L) Ascospores with germ pores at the ends. Scale bars: $B=60 \mu \mathrm{m}, C=30 \mu \mathrm{m}, D-F=10 \mu \mathrm{m}, G-L=5 \mu \mathrm{m}$.

Material examined: SWITZERLAND, Genève, on internal side of dead bark of Malus domestica (Rosaceae), 1819, Prost (G: No.53, holotype).

Lecanidiella Sherwood, Sydowia 38: 272 (1986) [1985]

Facesoffungi number: FoF 00353

Type species: Lecanidiella contortae Sherwood, Sydowia 38: 274 (1986) [1985]

Facesoffungi number: FoF 00354

Fig. 8 
Saprobic on bark of Pinus contorta in terrestrial habitats. Sexual morph: Ascomata 12-19 $\times$ 4-7 mm, apothecial, scattered in bark, closed and immersed in host tissue when young, erumpent through host surface at maturity and exposed with ash-like hymenium, irregular at the rim, rough, slightly serrate, carbonaceous, black. Exciple $70-155 \mu \mathrm{m}$ wide $(\bar{x}=100 \mu \mathrm{m} ; \mathrm{n}=10)$, outer layers pseudoparenchymatous, thick-walled, black, inner layers composed of cells textura angularis. Hamathecium composed of 1.5-2 $\mu \mathrm{m}$ wide, branched, filamentous, hyaline, pseudoparaphyses, forming a pale brown epithecium above the asci. Asci $80-115 \times 12-17 \mu \mathrm{m}(\bar{x}=105 \times 15 \mu \mathrm{m} ; \mathrm{n}=$ 10), bitunicate, cylindrical, clavate, short pedicellate, and slightly broad at the apex, with an ocular chamber Ascospores 14-15.5 $\times(5.5-) 6-7.5 \mu \mathrm{m}(\bar{x}=15 \times 7 \mu \mathrm{m} ; \mathrm{n}=10), 1-2$-seriate overlapping, oblong, fusiform, with rounded ends, 3-septate, hyaline, smooth-walled. Asexual morph: Unknown.

Material examined: USA, Oregon, Linn County, Barren area near Santiam Summit, on bark of Pinus contorta Douglas (Pinaceae), 12 June 1983, Sherwood and Pike (BPI 674929, holotype).

Notes: Lecanidiella was described by Sherwood (1980) as a monotypic genus which is known to have distribution in the mountain areas of western North America. Sherwood (1986) confirmed the observation made by Pirozynski \& Reid (1966) and Petrini et al. (1979) that both Lecanidiella and Holmiella have apothecial ascomata which are initially enclosed in host parenchyma, and subsequently crack open to become finally exposed through a wide, irregular hymenium. Pirozynski \& Reid (1966) and Petrini et al. (1979) also showed that Lecanidiella and Holmiella are different in ascospores characters (Sherwood 1980). Sherwood (1986) studied the relatedness of Lecanidiella, Lecanidion (current name is Patellaria in Patellariaceae) and Melittosporiella (from Rhytismatales) and concluded that Lecanidiella and Melittosporiella are not related. However, she retained Lecanidiella in Patellariaceae in view of its intermediate nature between Patellariaceae and propoloid Rhytismatales. Kutorga \& Hawksworth (1997) reported Lecanidiella as having ascomata as apothecioid, erumpent, black, serrated at the rim, a brown and powdery epithecium, bitunicate asci, ascospores with 3-septate. Lumbsch \& Huhndorf (2010) accommodated Lecanidiella in Patellariaceae.

Lirellodisca Aptroot, in Aptroot \& Iperen, Nova Hedwigia 67(3-4): 485 (1998)

Type species: Lirellodisca pyrenulispora Aptroot, Nova Hedwigia 67(3-4): 485 (1998) Fig. 9

Facesoffungi number: FoF 00356

Saprobic on twigs of Elaeocarpus sp. in terrestrial habitat. Sexual morph: Ascomata 1,1252,350 × 380-455 $\mu \mathrm{m}$, apothecial, solitary, scattered, erumpent in bark, superficial, subglobose, deeply cup-shaped, with rim slightly raised over the centre, thick-walled, black. Exciple 85-135 $\mu \mathrm{m}$ wide, composed of 2 layers, outer cell layer pseudoparenchymatous, black, inner cell layer comprised thick-walled isodiametric cells, continuous from the base to the margin, with gelatinized, light brown to colourless cells. Hamathecium composed of up to $1 \mu \mathrm{m}$ wide, filamentous, individual, apically branched, hyaline, pseudoparaphyses, embedded in a gelatinous matrix, forming a pale brown epithecium. Asci 100-180 × 15-23 $\mu \mathrm{m}(\bar{x}=145 \times 20 \mu \mathrm{m} ; \mathrm{n}=10)$, 8-spored, bitunicate, cylindrical to oblong, slightly broad on the apex, narrow in the lower part, long pedicellate, with indistinct ocular chamber. Ascospores $25-35 \times 10-12 \mu \mathrm{m}(\bar{x}=28 \times 10 \mu \mathrm{m} ; \mathrm{n}=$ 10), 2-seriate, ellipsoidal, curved, rounded at the ends, mostly with 6-transverse distosepta, cells with reduced cell-lumen, hyaline, smooth-walled. Asexual morph: Unknown.

Material examined: PAPUA NEW GUINEA, Owen Stanley Range, Myola, along trail from guesthouse to Naduri, on twigs of Elaeocarpus sp. (Elaeocarpaceae) in primary montane forest, 909'S, 147²6' E. Altitude 2100 m., 17 October 1995, A. Aptroot 38022 (CBS H-6148, holotype).

Notes: Typified by Lirellodisca pyrenulispora, the monotypic genus Lirellodisca was introduced by Aptroot \& Iperen (1998) based on a collection from Elaeocarpus sp. and is characterized by distoseptate ascospores. Lirellodisca was placed in Patellariales, although the genus shows some similarity with Arthoniales. Lirellodisca has cup-shaped ascomata and thickwalled distoseptate ascospores which are different from Arthoniales and Phyneromyces (Aptroot \& Iperen 1998). In this study, we accept Lirellodisca in Patellariaceae in view of its cup-shaped ascomata and filamentous pseudoparaphyses forming an epithecium above the bitunicate asci. 

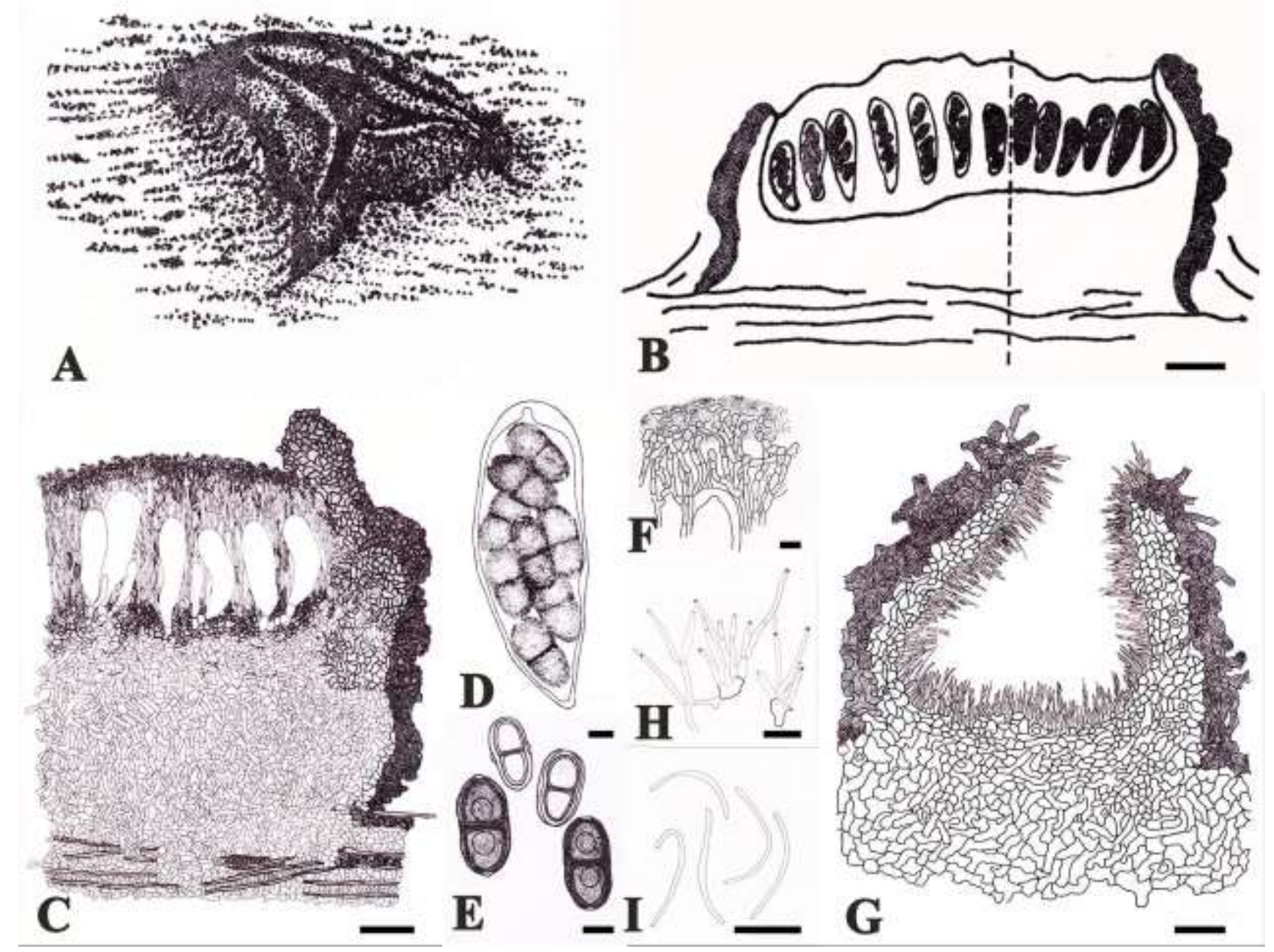

Fig. 6 - Homeilla sabina (Redrawn from Petrini et al., 1978). (A) Apothecia on host surface. (B) Vertical section of apothecium. (C) Peridium of textura angularis. (D) Asci with 8-spored. (E) Development of ascospores. (F) Epithecium formed over the asci. (G) Section of pycnidium growing in OA agar. $(\mathrm{H})$ Conidiophore with phialidic conidiogenous cell found in culture. (I) Conidia formed in culture. Scale bars: $B=100 \mu \mathrm{m}, C=50 \mu \mathrm{m}, D-F, H-J=10 \mu \mathrm{m}, G=25 \mu \mathrm{m}$.

Murangium Seaver, North American Cup-fungi, (Inoperculates) (New York): 367 (1951)

Facesoffungi number: FoF 00357

Notes: The monotypic genus Murangium was established by Seaver (1951) and accommodated in Cenangiaceae. Morphologically, the genus is characterized by apothecial ascomata as in Cenangium and arranged in small clusters with cup-shaped apothecia, and with an irregular aperture and with bitunicate asci and muriform ascospores. Korf \& Zhuang (1987) noted the fissitunicate nature of the asci in Murangium sequoiae. However, Eriksson (1982) noted that cup-shaped, apothecial ascomata and bitunicate, fissitunicate asci in Murangium are characters belonging to Patellariaceae. Kutorga \& Hawksworth (1997) confirmed that M. sequoiae has similarity with other members in Patellariaceae, viz. Holmiella and Tryblidaria. Bonar (1942) tried to grow the asexual morph of M. sequoiae on sterilized twigs of Sequoia in vitro but was not successful. In this study, we examined a specimen of $M$. sequoiae obtained from NY. The morphology shows similarity with other members of Patellariaceae where this genus is retained.

Type species: Murangium sequoia (Plowr. ex W. Phillips) Seaver, North American Cup fungi (Inoperculates) (New York): 368 (1951)

$\equiv$ Cenangium sequoia Plowr., Grevillea 7(no. 41): 23 (1878)

Fig. 10

Facesoffungi number: FoF 00358 
Saprobic on bark of Sequoiadendron giganteum (Lindl.) J. Buchh. in terrestrial habitats. Sexual morph: Ascomata 1320-1560 × 485-630 $\mu \mathrm{m}$, apothecial, aggregated in small groups, superficial, mostly in linear, some solitary, closed when young, opened as inverted cone to deep cup, with an exposed hymenium at maturity, folded at the rim, thick, slightly raised over the centre with lobes, irregular, black. Exciple 10-18 $\mu \mathrm{m}$ wide, composed of 2 layers, outer layer pseudoparenchymatous, black, inner layer comprised with textura globulosa to textura angularis. Hamathecium composed of 1.5-2 $\mu \mathrm{m}$ wide, filamentous, septate, branched, pseudoparaphyses, rounded at the apex, anastomosed to form a dark epithecium over the asci, turning dark of greenblue in 5\% KOH solution. Asci 215-440 × 60-145 $\mu \mathrm{m}(\bar{x}=335 \times 100 \mu \mathrm{m} ; \mathrm{n}=10)$, 8-spored, bitunicate, clavate to broadly, indistinctly apically domed, narrow and short at the base. Ascospores 85-153 × 37-75 $\mu \mathrm{m}(\bar{x}=106 \times 49 \mu \mathrm{m} ; \mathrm{n}=10), 2$-seriate overlapping, ellipsoid to obovoid, oblong, rounded at the ends, with 4-7-transverse and 1-2-longitudinal septa, slightly constricted at the central septa, hyaline when immature, brown when mature. Asexual morph: Unknown.

Material examined: USA, California, Yosemite, on a bark of Sequoiadendron giganteum (Lindl.) J. Buchh. (Cupressaceae), 1951, Bonar (NY, n.P. v1.23.33).

Poetschia Körb., Parerga lichenol. (Breslau): 280 (1861)

Facesoffungi number: FoF 00359

Saprobic on bark in terrestrial habitats. Sexual morph: Ascomata apothecial, scattered, superficial, mostly sessile, closed when young and becoming open when mature, globose, black, with the rim slightly elevated than the center, becoming convex when rehydrated. Exciple pseudoparenchymatous, 2-layered, cells of outer layer thick and black, inner layer comprising thin cells of textura angularis. Hamathecium composed of unbranched, hyaline, septate, pseudoparaphyses, with slightly swollen cells forming a dark epithecium above the asci. Asci bitunicate, 8-spored, thin-layered when mature, obovoid, clavate, broad, short pedicellate, with a thick ocular chamber. Ascospores irregularly arranged, ellipsoidal to obovoid, with wide upper cell and narrow lower cell, 1-septate, constricted at the septa, gray brown to brown, smooth-walled. Asexual morph: Unknown.

Note: Koerber (1861) introduced Poetschia with a single species and placed it in the family Calycieae and subfamily Lahmiea. The genus was synonymized under Karschia Körb. by Saccardo (1889). However, the generic concept of Poetschia was expanded and recognized by Hafellner (1979) who transferred the genus Poetschia to Dothideales without mentioning the family name. Four species and two varieties were included. Poetschia was transferred to the family Patellariaceae by Kutorga \& Hawksworth (1997) with four accepted species viz. Poetschia andicola (Speg) Hafellner, P. buellioides Körb., P. caerulescens (Hafellner) Kutorga and Hawksworth and $P$. cratincola (Rehm) Hafellner. based on apothecial ascomata, a receptacle with pseudoparenchyma and bitunicate asci. These characters were confirmed in our study, thus we retain Poetschia in Patellariaceae, pending molecular studies.

Type species: Poetschia buellioides Körb., Parerga lichenol. (Breslau): 280 (1861) Fig. 11

Facesoffungi number: FoF 00360

Saprobic on bark of Malus domestica in terrestrial habitats. Sexual morph: Ascomata 250 $260 \times 115-135 \mu \mathrm{m}$, apothecial, scattered, superficial, mostly sessile, closed when young and becoming open when mature, globose, black, with the rim slightly elevated over the center, convex after rehydration. Exciple $20-25 \mu \mathrm{m}$ wide $(\bar{x}=24 \mu \mathrm{m} ; \mathrm{n}=10)$, pseudoparenchymatous, 2-layered, black with outer layer, inner layer thin, with cells of textura angularis. Hamathecium composed of 1.5-2 $\mu \mathrm{m}$ wide $(\bar{x}=2 \mu \mathrm{m} ; \mathrm{n}=10)$, cylindrical, unbranched, hyaline, septate pseudoparaphyses, with slightly swollen rounded cells at the apex, forming a dark epithecium above the asci. Asci $37-$ $55 \times 8-23 \mu \mathrm{m}(\bar{x}=13 \times 47 \mu \mathrm{m} ; \mathrm{n}=10), 8$-spored, bitunicate, obovoid to clavate, broad, shortpedicellate, with a wide ocular chamber. Ascospores $15-20 \times 7-10 \mu \mathrm{m}(\bar{x}=20 \times 9 \mu \mathrm{m} ; \mathrm{n}=10)$, irregularly arranged, ellipsoidal to obovoid, upper cell wide, basal cell narrow, pointed at both ends, 1-septate, constricted at the septa, gray brown to brown, smooth-walled. Asexual morph: Unknown. 

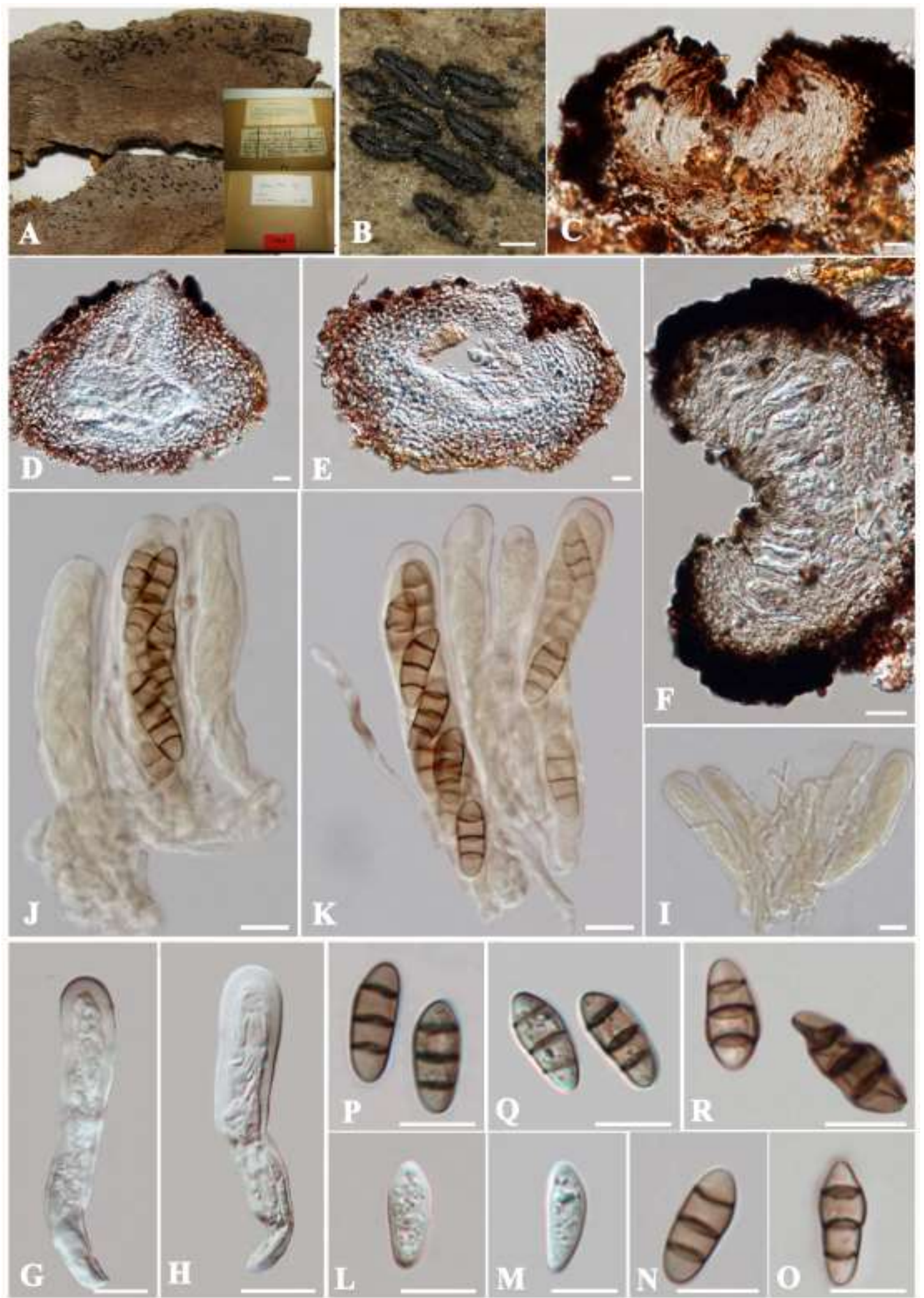

Fig. 7 - Hysteropatella prostii (G: No.53, holotype). (A) Hysterothecia on host surface. (B-F) Vertical section of apothecium and peridium comprising cells of textura angularis. (G-I) Young asci with pseudoparaphyses. (J, K) Mature asci with 8-spored. (L-R) Ascospores. Scale bars: $B=$ $200 \mu \mathrm{m}, C-F=25 \mu \mathrm{m}, G-R=10 \mu \mathrm{m}$.

Material examined: AUSTRIA, Scheibbs, Gresten, on the bark of Malus domestica Borkh (Rosaceae), Poetsch (L4192, N910.204-614, isotype). 

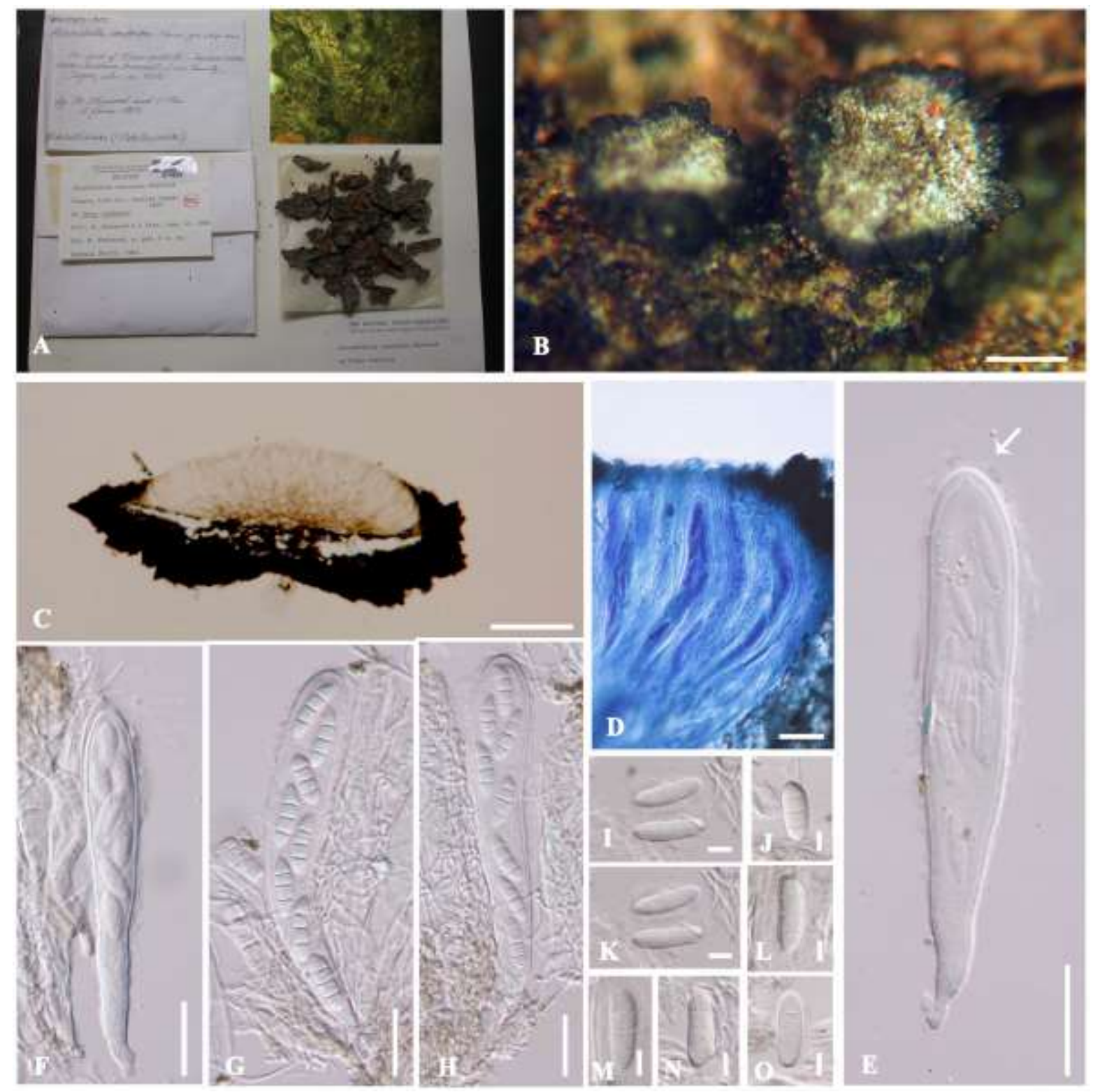

Fig. 8 - Lecanidiella contortae (BPI 674929, holotype). (A) Herbarium specimen. (B) Apothecia on bark of Pinus contorta. (C) Vertical section of apothecium. (D) Asci embedded in gelatinous mass. (E, F) Immature asci with ocular chamber (arrowed). (G, H) Mature asci with 8-spored. (I-O) Ascospores. Scale bars: $C=150 \mu \mathrm{m}, D-H=20 \mu \mathrm{m}, I-O=5 \mu \mathrm{m}$.

Rhizodiscina Hafellner, Beihefte zur Nova Hedwigia, 62: 195 (1979)

Facesoffungi number: FoF 00361

Saprobic on Oak trees (Quercus sp.) and on basidiomata of Aphyllophorales in terrestrial habitats. Sexual morph: Ascomata apothecial, in small groups or scattered on the bark, superficial, closed when young, exposed with black velvety hymenium at maturity, slightly thick, crenulated and arising above at the rim, with a convex outline, with black anchoring base. Exciple pseudoparenchymatous, with black outer layers, discontinuously merged with host surface, with inner layers composed of densely arranged cells of textura angularis, thicker than outer layer, dark brown. Hamathecium composed of 1.5-2 $\mu \mathrm{m}$ wide, thick, branched, hyaline, septate pseudoparaphyses, slightly swollen on the apex, anastomosed, forming a light brown epithecium above or at the level of asci. Asci bitunicate, clavate, long pedicellate, wide at the apex, with wide ocular chamber. Ascospores irregularly arranged, obovoid to oblong, 1-septate, brown, with slightly swollen upper cell, slender in the remaining part, rounded at the ends, constricted at the septa, smooth-walled. Asexual morph: Unknown. 

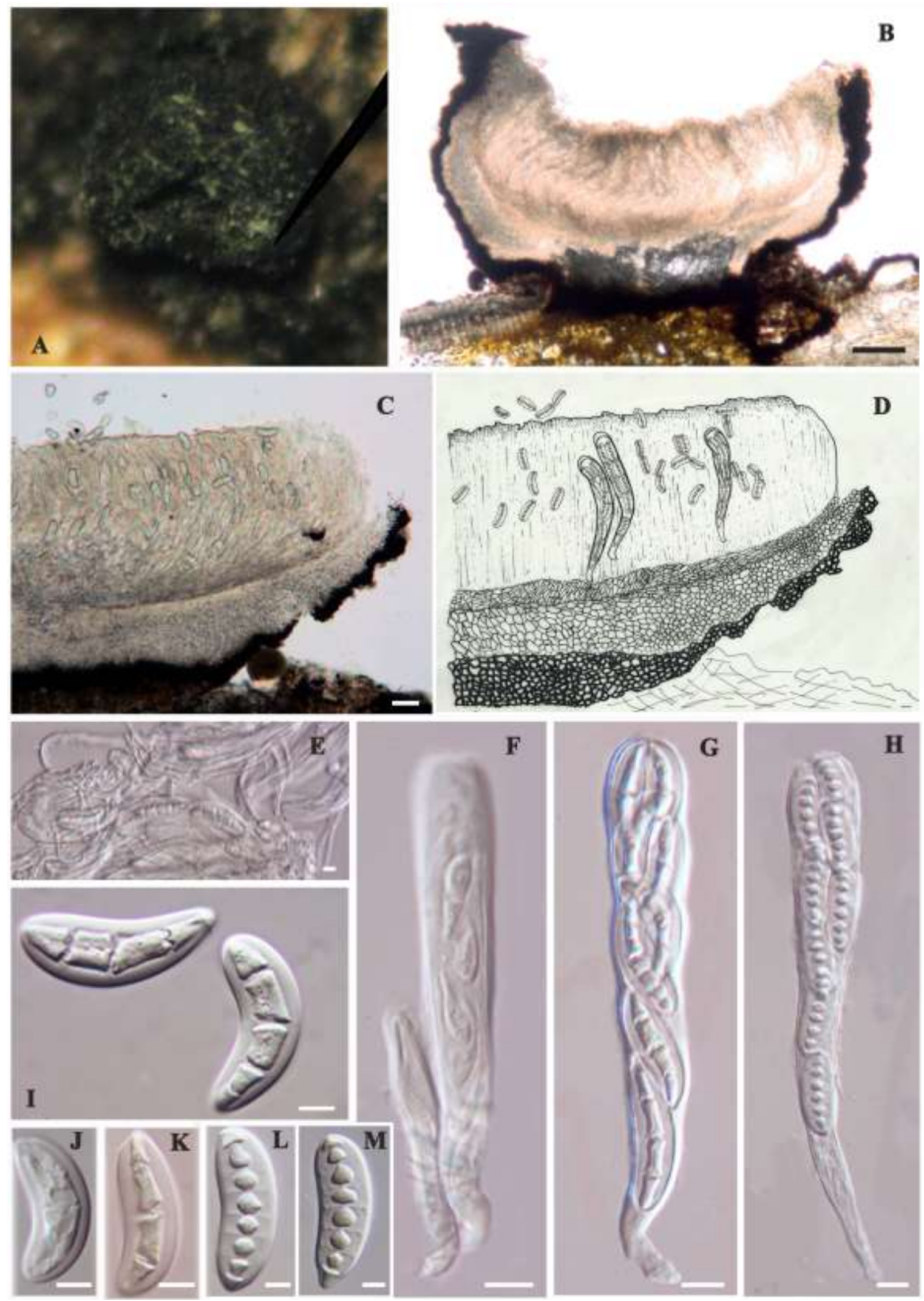

Fig. 9 - Lirellodisca pyrenulispora (CBS H-6148, holotype). (A) Ascoma on host tissue. (B) Hand section of apothecial ascomata. (C) Peridium tissue with 2 layers. (D) Drawing picture of vertical section with textura angularis in peridium. (E) Pseudoparaphyses as filamentous embedded in gelatinous. (F, G) Immature asci with indistinct ocular chamber. (H) Mature asci with 8-spored. (IK) Young ascospores. (L, M) Mature ascospores. Scale bars: $B=120 \mu \mathrm{m}, C=100 \mu \mathrm{m}, E=3 \mu \mathrm{m}, I$ $=7 \mu \mathrm{m}, F-H=10 \mu \mathrm{m}, I-M=5 \mu \mathrm{m}$. 

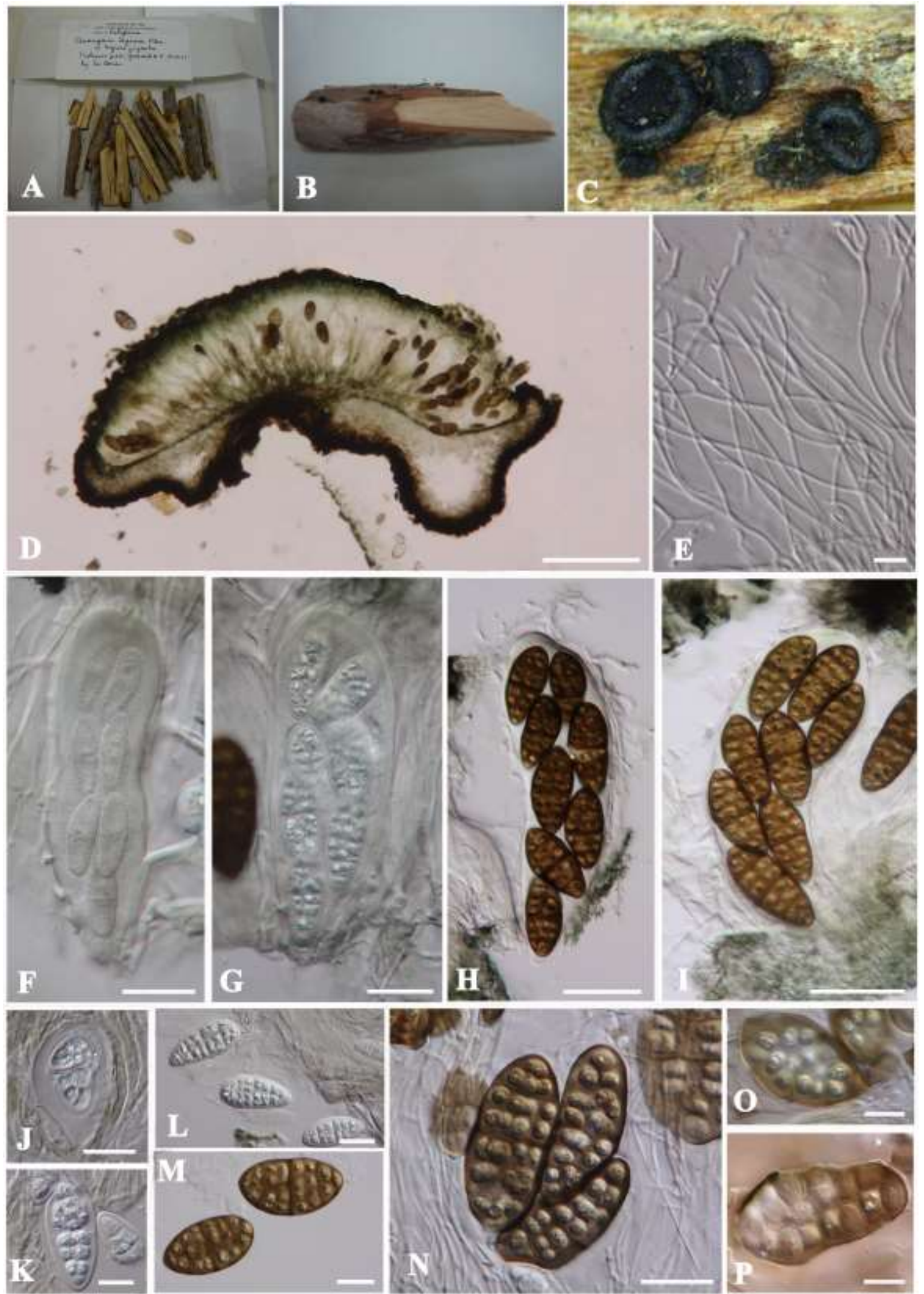

Fig. 10 - Murangium sequoia (NY, n.P. v1. 23. 33). (A, B) Herbarium package and herbarium specimen. (C) Ascoma aggregated on host surface. (D) Vertical section of ascoma. (E) Pseudoparaphyses as filamentous. (F, G) Young asci with hyaline ascospores. (H, I) Mature asci with 8 -spored. (J-L) Young ascospores. (M-Q) Mature ascospores. Scale bars: $D=300 \mu \mathrm{m}, E=40$ $\mu \mathrm{m}, F-I=50 \mu \mathrm{m}, J-M, O-P=30 \mu \mathrm{m}, N=50 \mu \mathrm{m}$. 
Notes: Hafellner (1979) re-studied Peziza lignyota Fr. and transferred the taxon to the new genus Rhizodiscina. He included Rhizodiscina in Patellariaceae which was followed by Barr (1987) and Eriksson \& Hawksworth (1993). Presently, there are two species in this genus $R$. lignyota (Fr.) Hafellner and R. proteae Marinc., M.J. Wingf. and Crous (Index Fungorum, 2014). Kutorga \& Hawksworth (1997) reported that many characters of $R$. lignyota are similar with Poetschia andicola: hamathecium, shape and size of asci and spores, epithecium and hyphae. However, one character used to distinguish Poetschia and Rhizodiscina, is the massive exciple in $R$. lignyota, which is nearly half of the ascoma, unlike in Poetschia andicola. We studied the neotype specimen from $M$ which designated by Hafellner (1979).

Type species: Rhizodiscina lignyota (Fr.) Hafellner, Beih. Nova Hedwigia 62: 195 (1979)

$\equiv$ Peziza lignyota Fr., Syst. mycol. (Lundae) 2(1): 150 (1822)

Fig.12

= Karschia lignyota (Fr.) Sacc., Syll. fung. (Abellini) 8: 779 (1889)

Facesoffungi number: FoF 00362

Saprobic on Oak trees (Quercus sp.) in terrestrial habitats. Sexual morph: Ascomata 580-625 $\times 204-208 \mu \mathrm{m}$, apothecial, superficial, in small groups or scattered on the bark, closed when young, exposing a black velvety hymenium at maturity, slightly thick, crenulated and rising above at the rim, convex in outline, with black anchoring base. Exciple $29-42 \mu \mathrm{m}$ wide $(\bar{x}=36 \mu \mathrm{m} ; \mathrm{n}=10)$, pseudoparenchymatous, black at outer layers, non-continuous, merged with host surface, inner layers composed of textura angularis, thicker than outer layer, with dense cells, dark brown. Hamathecium thick, composed of 1.5-2 $\mu \mathrm{m}$ wide, branched, septate, hyaline, pseudoparaphyses, slightly swollen at the apex, anastomosed, forming a light brown epithecium above or at the level of asci. Asci $45-50 \times 13-16 \mu \mathrm{m}(\bar{x}=47 \times 14 \mu \mathrm{m} ; \mathrm{n}=10)$, bitunicate, clavate, long pedicellate, wide at the apex, with a wide ocular chamber. Ascospores 9-14 $\times 4-5 \mu \mathrm{m}(\bar{x}=12 \times 5 \mu \mathrm{m} ; \mathrm{n}=10)$, irregularly arranged, obovoid to oblong, upper cell slightly swollen, slender in the remaining part, rounded at the ends, constricted at the septa, 1-septate, brown, smooth-walled. Asexual morph: Unknown.

Material examined: GERMANY, Bavaria, Franken, Sugenheim, in the forest near Sugebheim, on rotting twigs of Quercus sp. (Fagaceae) 1869, H. Rehm (M 0177903, neotype)

Other material examined: BELGIUM, Zonhoven, De Teut, 28 June 2007 (PB2007108); Bocholt, Lozerheide, on rotting stem, 19 March 2008 (PB2008016).

Schrakia Hafellner, Nova Hedwigia, Beihefte zur 62: 204(1979)

Facesoffungi number: FoF 00363

Notes: Schrakia was introduced by Hafellner (1979) in Dothideales genera incertae sedis with only one species, S. crassula. Subsequently, Schrakia was transferred to Patellariaceae by Eriksson and Hawksworth (1993), Hawksworth et al. (1995), Kutorga and Hawksworth (1997). The characters typical of Patellariaceae are carbonaceous apothecia and exciple with thick-walled and pseudoparenchymatous cells and bitunicate asci. Hafellner (1979) noted that in Schrakia ascomata structure is initially apothecioid and later becomes gymnocarpous which is different from the main character of Patellariaceae. Kutorga and Hawksworth (1997) included Schrakia in Patellariaceae. Index Fungorum (2014) lists Schrakia with 2 varieties (S. crassula var. aurantiaca Hafellner and $S$. crassula var. crassula (Starbäck) Hafellner). We retain this genus in Patellariaceae.

Type species: Schrakia crassula (Starbäck) Hafellner, Nova Hedwigia, Beihefte zur. 62: 204 (1979)

Fig. 13

$\equiv$ Karschia crassula Starbäck, Bih. K. svenska VetenskAkad. Handl., Afd. 3 25(no. 1): 10 (1899)

Facesoffungi number: FoF 00364

Saprobic on bark or lichen thalli in terrestrial habitats. Sexual morph: Ascomata $360 \times 186$ $\mu \mathrm{m}$, apothecial, superficial, scattered on thallus on bark, sub-globose to globose, on exposure becoming velvety at maturity, dark concave and indistinct at the border, dark brown at the receptacle, carbonaceous, black. Exciple 50-115 $\mu \mathrm{m}$ wide $(\bar{x}=76 \mu \mathrm{m} ; \mathrm{n}=10)$, 
pseudoparenchymatous, dark brown at outer layer, distinct at the margin and centre, thick-walled, with cells of textura angularis at the inner layer, pale brown, continuous with brown cells of hypothecium. Hamathecium composed of 1.5-2 $\mu \mathrm{m}$ wide, filliform to filamentous, septate, branched, pseudoparaphyses, forming a brown epithecium above asci. Asci 58-90 $\times 15-25 \mu \mathrm{m}(\bar{x}$ $=69 \times 20 \mu \mathrm{m} ; \mathrm{n}=10), 8$-spored, bitunicate, broadly clavate, long pedicellate, with a thick apical chamber. Ascospores $15-19 \times 8-9 \mu \mathrm{m}(\bar{x}=17 \times 8.5 \mu \mathrm{m} ; \mathrm{n}=10)$, irregulary arranged, rounded at the upper part, cells wider at the upper part, narrowly rounded at lower part, 1-septate, constricted at the centre, smooth-walled, guttulate, dark brown. Asexual morph: Unknown.

Material examined: BRAZIL, Rio Grande do Sul, on bark of unknown tree, 4 April 1893, Gust. A:n Malme 319 (S: F7154, holotype).

Stratisporella Hafellner, Beih. Nova Hedwigia 62: 207 (1979)

Facesoffungi number: FoF 00365

Notes: Stratisporella was introduced by Hafellner (1979) with a single species S. episemoides Hafellner. Its lichenicolous habit, apothecioid ascomata, and 1-septate ascospores with thick exospores were considered distinct. Hafellner (1979) noted the unitunicate nature of asci (although they appear bitunicate in his illustration) and hymenium gel turning blue in iodine. Kutorga \& Hawksworth (1997) treated this genus in Patellariaceae as they observed that the asci are bitunicate. In this study, a single herbarium slide was available for examination and the characters of the genus are hard to determine. However, the asci appear to be bitunicate. This taxon should be recollected and an epitype established with sequence data.

Type species: Stratisporella episemoides (Nyl.) Hafellner, Beih. Nova Hedwigia 62: 207 (1979)

$\equiv$ Lecidea episemoides Nyl., Lich. Angol. Welwitschiani: 10 (1869)

Figs. 14-15

=Karschia episemoides (Nyl.) Vouaux, Bull. Soc. mycol. Fr. 29: 462 (1913)

Facesoffungi number: FoF 00366

Parasitic on lichenized thallus of Tremotylium angolense Nyl. in terrestrial habitats. Sexual morph: Ascomata $300 \times 295 \mu \mathrm{m}$, apothecial, solitary, immersed, black, closed when young and disc-like to lentiform when mature, pyriform to clavate, similar to an inverted cone. Exciple 47-53 $\mu \mathrm{m}$, comprised of isodiametric cells, outer layer comprising brown to dark brown paraplectenchymatous cells, and inner layer of pale brown to brown cells of textura intricata. Hamathecium composed of 2-3 $\mu \mathrm{m}$ wide, cylindrical to filiform, septate, branched, pseudoparaphyses, forming a brown epithecium above asci. Asci 54-99 $\times 6-9 \mu \mathrm{m}(\bar{x}=84 \times 8 \mu \mathrm{m}$; $\mathrm{n}=10), 4-8$-spored, bitunicate, cylindrical, pedicellate, with an ocular chamber. Ascospores 15-19 $\times 5-8 \mu \mathrm{m}(\bar{x}=16 \times 7 \mu \mathrm{m} ; \mathrm{n}=10)$, uni-seriate overlapping, ellipsoidal to slightly oblong, broader at the upper part, asymmetrically1-transverse septate, with a conspicuous thick exospore, pale to brown, with warty surface. Asexual morph: Unknown.

Material examined: ANGOLA, on thallus of Tremotylium angolense Nyl. (Thelotremataceae), 1864, F.M.J. Welwitsch (H-Nyl 10975, holotype).

Tryblidaria (Sacc.) Rehm, Hedwigia 42: 173 (1903)

三Blitrydium subgen. Tryblidaria Sacc., Syll. Fung. (Abellini) 8: 805 (1889)

Facesoffungi number: FoF 00367

Saprobic on bark in terrestrial habitats. Sexual morph: Ascomata apothecial, superficial, cupshaped, scattered, occasionally in groups of 3-5, globose, carbonaceous, gray or black, with raised rim. Peridium (exciple) relatively wide, carbonaceous, dark brown, comprising pseudoparenchymatous cells, which are hard to distinguish. Hamathecium composed of filamentous, unbranched, trabeculate, filiform, hyaline, pseudoparaphyses, embedded in a gelatinous matrix, forming a light brown epithecium above the asci. Asci 8-spored, bitunicate, broadly clavate, wide in the middle, narrow at the base with a long pedicel, narrow at the apex, with an indistinct ocular chamber. Ascospores 1-2-seriate overlapping, ellipsoidal to oblong, multiseptate or muriform, hyaline to light brown. Asexual morph: Unknown. 

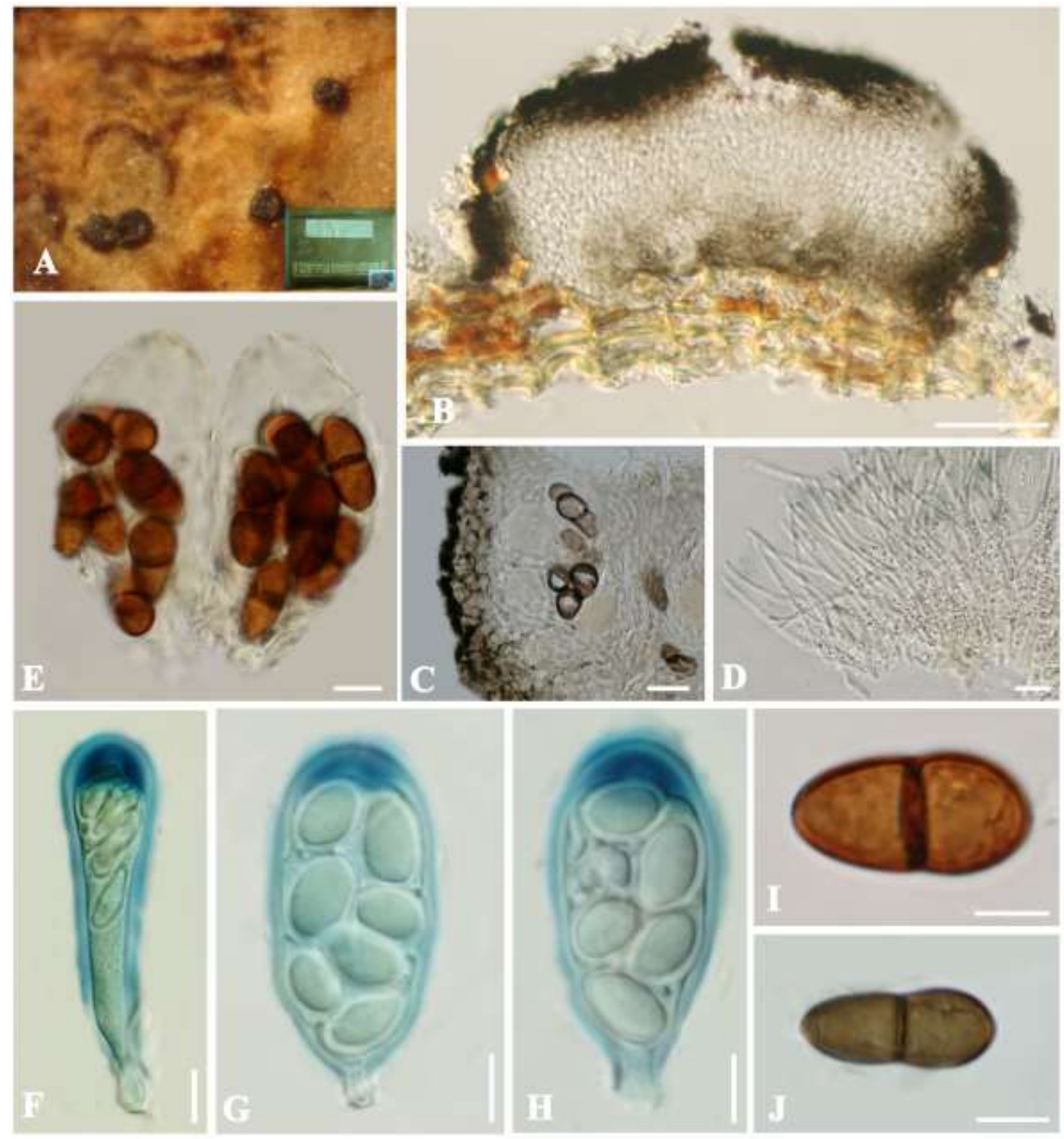

Fig. 11 - Poetschia buellioides (L4192, N910.204-614, isotype). (A) Apothecia on host tissue. (B) Cross section of apothecia. (C) Peridium comprising textura angularis. (D) Elongated and unbranched filaments of hamathecium. (E) Bitunicate asci with thin layer. (F-H) Young asci stained in Meltzer's reagent. (I-J) Ascospores. Scale bars: $A=100 \mu \mathrm{m}, B=30 \mu \mathrm{m}, C, D=10 \mu \mathrm{m}$, $E-J=5 \mu \mathrm{m}$.

Notes: Saccardo (1889) divided Blitrydium into two subgenera; Eu-Blitrydium and Tryblidaria and Rehm (1904) raised Tryblidaria to generic rank (Kutorga \& Hawksworth 1997). Clements \& Shear (1931) grouped Tryblidaria under Patellariacae and designated T. fenestrata (Cooke \& Peck) M.E. Barr as the type species of the genus and this was followed in Kutorga \& Hawksworth (1997). Index Fungorum (2014) however, lists T. breutelii Rehm as the type species belonging to Patellariaceae and this needs revision, especially as T. breutelii is lichenized. Index Fungorum (2014) lists 31 epithets. In this study, we examined specimens of T. fenestrata from Kew (K(M) 32624, lectotype), CUP-D (CUP-D-07132(111-151), isolectotype) and BPI (675178, 675179), isolectotype). We illustrate the lectotype from $\mathrm{K}$ and $T$. breutelii holotype which is clearly not related to T. fenestrata. 

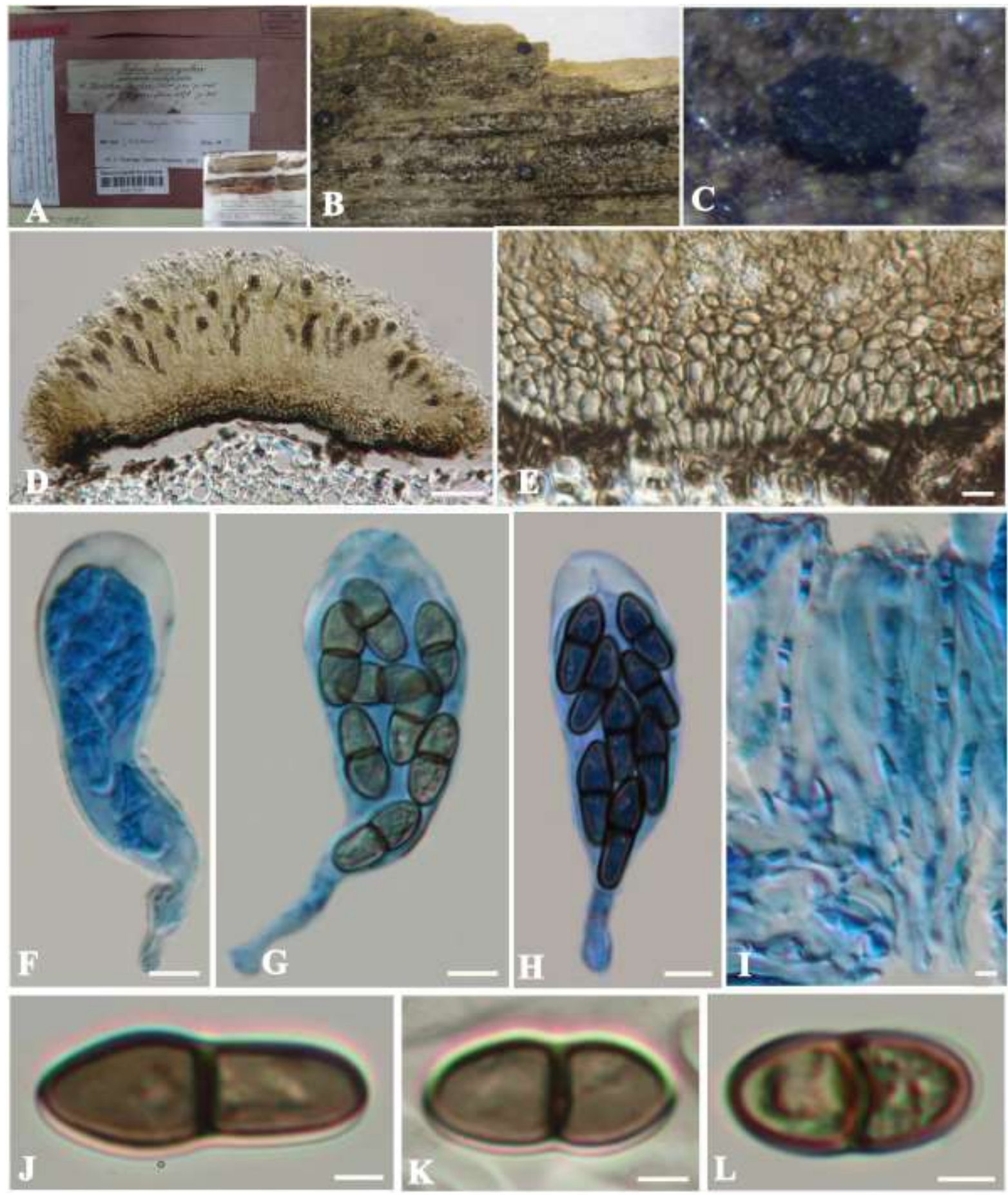

Fig. 12 - Rhizodiscina lignyota (M 0177903, neotype). (A) Herbarium specimen, (B, C) Fruiting body on host tissue. (C) Vertical section of ascoma. (D) Section of exciple. (F) Immature asci stained in cotton blue. (G, H) Mature bitunicate with 8-spored. (I) Hamathecium with septate, filaments. (J-L) Several kinds of mature ascospores. Scale bars: $D=50 \mu \mathrm{m}, E=10 \mu \mathrm{m}, F-H=5$ $\mu \mathrm{m}, I-L=2 \mu \mathrm{m}$.

Type species: Tryblidaria fenestrata (Cooke \& Peck) M.E. Barr, in Barr et al., Bull. N.Y. St. Mus.: 22 (1986) Fig. 16

$\equiv$ Patellaria fenestrata Cooke \& Peck, Ann. Rep. N.Y. St. Mus. nat. Hist. 28: 68 (1876)

Facesoffungi number: FoF 00368

Saprobic on dead branches of Populus sp. in terrestrial habitats. Sexual morph: Ascomata 1,315$1,860 \times 295-440 \mu \mathrm{m}$, apothecial, superficial, scattered, solitary, black, closed when young, opened to expose the hymenium at maturity, subglobose to globose, convex, waxy at the center, 


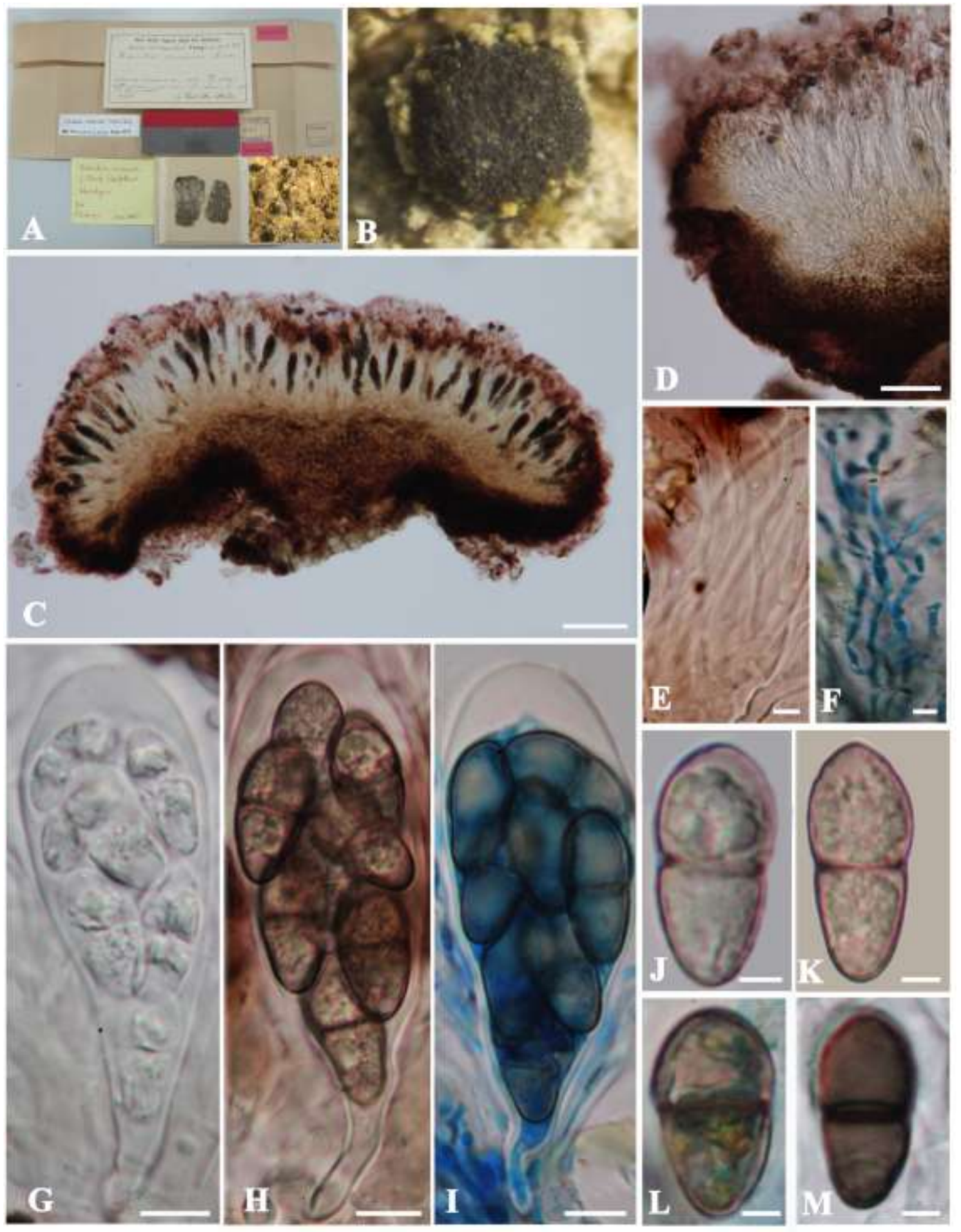

Fig. 13 - Schrakia crassula (S: F7154, holotype). (A) Herbarium specimen. (B) Apothecium on host surface. (C) Vertical section of ascoma. (D) Peridium. (E, F) Hamathecium with septate, filiform pseudoparaphyses (stained in cotton blue in F). (G-I) Bitunicate asci with 8-spored. (J-M) Young and mature 1-septate ascospores. Scale bars: $C=50 \mu \mathrm{m}, D=15 \mu \mathrm{m}, E, F=5 \mu \mathrm{m}, G-I=7$ $\mu \mathrm{m}, J-M=3 \mu \mathrm{m}$.

raised and rolled at the rim, rough, slightly raised than the center. Exciple $40-85 \mu \mathrm{m}$ wide $(\bar{x}=62$ $\mu \mathrm{m} ; \mathrm{n}=10$ ), prosenchymatous, with a dark outer layer, comprising cells of textura prismatica, inner layer with colorless, elongate and radiating cells continuous to the base (hypothecium). Hamathecium composed of 2-3 $\mu \mathrm{m}$ wide cylindrical, hyaline, septate, pseudoparaphyses, swollen on the apex, anastomosed, forming a black epithecium. Asci $18-47 \times 105-160 \mu \mathrm{m}(\bar{x}=135 \times 35$ 
$\mu \mathrm{m} ; \mathrm{n}=10$ ), 8-spored, bitunicate, clavate to oblong, slightly narrow at the apex, with an ocular chamber, short pedicellate. Ascospores 35-45 × 14-15 $\mu \mathrm{m}(\bar{x}=40 \times 15 \mu \mathrm{m} ; \mathrm{n}=10), 1-2$-seriate overlapping, obovoid or ellipsoid, oblong, multi-septate or muriform, slightly constricted at the septa, narrow at the lower part, hyaline to brown, with a thick mucilaginous sheath. Asexual morph: Unknown.

Material examined: USA, New York, Albany Country, Karner, on dead branches of Populus sp. (Salicaceae), November, C.H. Peck (K(M) 32624, lectotype); USA, New York, on dead branches of Populus sp. (Salicaceae), ex. collection of C. H. Peck (CUP-D-07132 (111-151), isolectotype), USA, New York, Albany Country, Center, Karner, on dead branches of Populus sp. (Salicaceae), C. H. Peck (BPI 675178, 675179, isolectotype).

Tryblidaria breutelii Rehm, Hedwigia 42: 173 (1903)

Fig. 17

Facesoffungi number: FoF 00371

Saprobic on bark of Anagyris foetida L. in terrestrial habitats. Sexual morph: Ascomata 268$420 \times 178-255 \mu \mathrm{m}$, apothecial, cup-shaped, scattered, occasionally in groups of 3-5, superficial, globose, carbonaceous, gray or black with raised rim. Exciple 38-82 $\mu \mathrm{m}$ wide $(\bar{x}=54 \mu \mathrm{m} ; \mathrm{n}=10)$, with carbonaceous, dark brown, pseudoparenchymatous cells, which are hard to distinguish. Hamathecium composed of filamentous, unbranched, hyaline, trabeculate, very narrow pseudoparaphyses, embedded in a gelatinous matrix, forming a light brown epithecium above the asci. Asci 103-130 × 17-34 $\mu \mathrm{m}(\bar{x}=116 \times 26 \mu \mathrm{m} ; \mathrm{n}=10), 8$-spored, bitunicate, broadly clavate, wide in the middle, narrow at the base with a long pedicel, narrow at the apex, with an indistinct ocular chamber. Ascospores 29-44 × 13-18 $\mu \mathrm{m}(\bar{x}=40 \times 16 \mu \mathrm{m} ; \mathrm{n}=10)$, 2-seriate overlapping, ellipsoidal to oblong, multi-septate or muriform, hyaline to light brown, surrounded by a thin mucilaginous sheath. Asexual morph: Unknown.

Material examined: SOUTH AFRICA, Eastern Cape, Betania, on the surface of Anagyris foetida L. (Fabaceae), 14 June 1902, Breutel (S: F61102, holotype of Tryblidaria breutelii Rehm).

\section{Genera excluded from Patellariaceae}

\section{Dothideomycetes, Hysteriaceae}

For notes on Hysteriaceae see Boehm et al. (2009a, b) and Hyde et al. (2013).

Rhytidhysteron Hafellner Anal. Soc. cient. argent. 90(1-6): 177(1921; 1920)

= Brunaudia (Sacc.) Kuntze, Revis. gen. pl. (Leipzig) 3(2): 447 (1898)

= Eutryblidiella (Rehm) Höhn., Sydowia 13(1-6): 241 (1959)

= Rhytidhysterium Sacc., (1883)

= Rhytidopeziza Speg., Anal. Soc. cient. argent. 19(6): 264 (1885)

$=$ Tryblidiella Sacc., Syll. fung. (Abellini) 2: 757 (1883)

= Tryblidiella sect. Eutryblidiella Rehm, Annls mycol. 2(6): 523 (1904)

Facesoffungi number: FoF 00369

Saprobic on living or dead wood in terrestrial habitats. Sexual morph: Ascomata when wet, apothecial, superficial, aggregated, black, rounded to boat-shaped, or irregular in shape, coriaceous, with rounded opening, folded at the margin, transversely notched, red or yellow at the center, when dry typical of hysterothecia or triangular and powdery, with elongate slit. Exciple composed of 2 layers, outer layer of pseudoparenchymatous cells with dark-brown walls, inner layer of pale brown to hyaline cells a textura globulosa. Hamathecium comprising of 1.5-3 $\mu \mathrm{m}$ wide, dense, cylindrical, hyaline, septate, unbranched, pseudoparaphyses, which fuse and are slightly swollen at the apex, forming a dark epithecium from above. Asci 6-8-spored, bitunicate, cylindrical, rounded at the apex, with a distinct of apical chamber. Ascospores uni-seriate overlapping, ellipsoidal to fusiform, slightly rounded at both ends, 1-3-septate, slightly constricted at the central septa, reddish-brown to brown. Asexual morph: "Diplodia"-like and "Aposphaeria"-like (Kutorga \& Hawksworth 1997). 

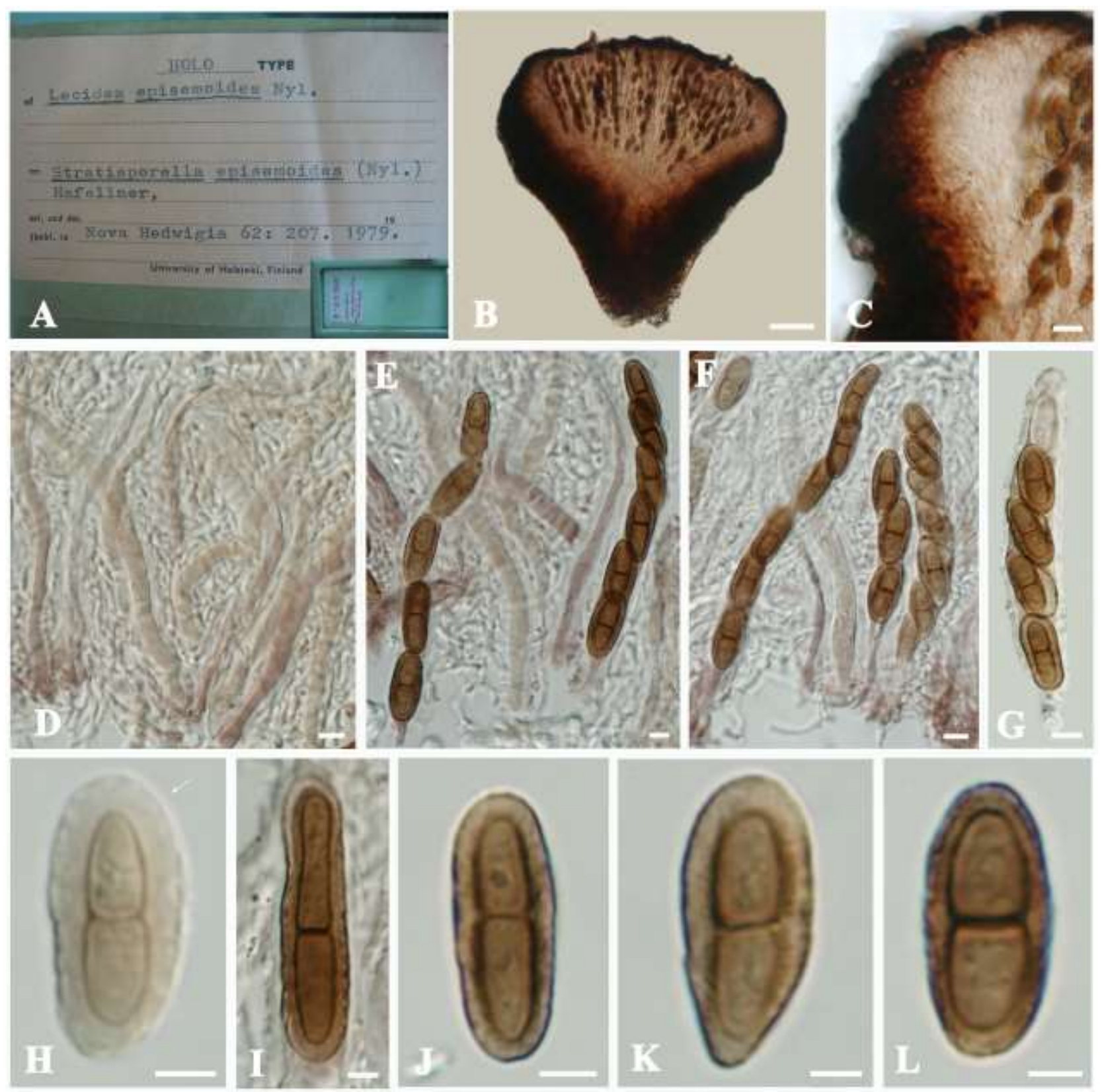

Fig. 14 - Stratisporella episemoides (H-Nyl 10975, holotype). (A) Herbarium package. (B) Vertical section of apothecium. (C) Peridium. (D) Hamathecium of pseudoparaphyses with young asci. (E-G) Young and mature asci with 4-8 ascospores. (H-L) Ascospore with exospore on surface (arrowed). Scale bars: $B=50 \mu \mathrm{m}, C-G=15 \mu \mathrm{m}, H-L=10 \mu \mathrm{m}$.

Notes: Rhytidhysteron was introduced by Spegazzini (1881) with two species ( $R$. brasiliense Speg. and $R$. viridie Speg.) without a type species being designated, while Clements \& Shear (1931) selected $R$. brasiliense as the type species for the genus. Rhytidhysteron brasiliense was synonymized under $R$. rufulum (Spreng.) Speg. by Samuels \& Müller (1979). Asexual morphs have been reported as Diplodia- and Aposphearia-like (Kutorga \& Hawksworth 1997). Von Arx \& Müller (1975) placed Rhytidhysteron in Patellariaceae and this has generally been followed (Kutorga \& Hawksworth 1997, Barr 1987, Eriksson 2006, Lumbsch \& Huhndorf 2010). Recently, this genus was transferred to Hysteriaceae by Boehm et al. (2009a, b) and Schoch et al. (2009) based on molecular data. However, Boehm (2009a, 2009b) suggested that fungi in this group is typically with Hysteriaceae rather than Patellariaceae. These placements were followed in Hyde et al (2013), Almeida et al. (2014) and Wijayawardene et al. (2014). 

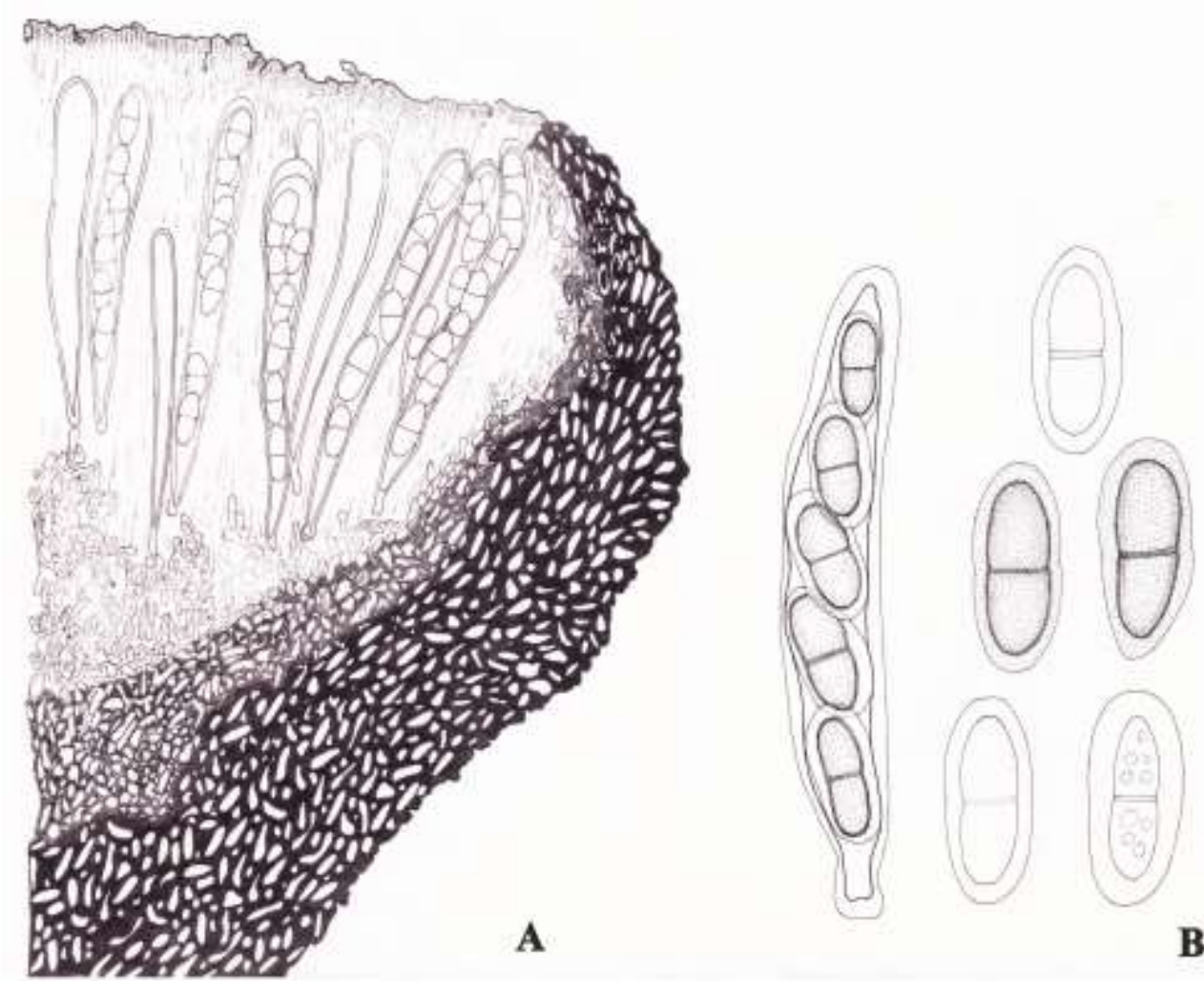

B

Fig. 15 - Stratisporella episemoides (A redrawn from Hafellner 1979; B redrawn from permanent slide sample: H-Nyl10975, holotype). (A) Section of ascoma with cells of textura intricata. (B) Bitunicate ascus with conspicuous thick exospore on ascospores.

Type species: Rhytidhysteron brasiliense Speg., Anal. Soc. cient. argent. 12(4): 188 (1881)

Facesoffungi number: FoF 00370

Fig. 18

Saprobic on living or dead wood in terrestrial habitats. Sexual morph: Ascomata when wet 1 $\times 2 \mathrm{~mm}$, apothecial, superficial, aggregated, black, rounded to boat-shaped, or irregular in shape, coriaceous, with rounded opening, folded at the margin, transversely notched, red or yellow at the center, when dry typical of hysterothecia or triangular and powdery, with elongate slit. Exciple 120-155 $\mu \mathrm{m}$ wide, composed of 2 layers, outer layer of pseudoparenchymatous cells with dark brown walls, inner layer of pale brown to hyaline cells a textura globulosa. Hamathecium comprising 1.5-3 $\mu \mathrm{m}$ wide, dense, cylindrical, hyaline, septate, unbranched, pseudoparaphyses, which fuse and are slightly swollen at the apex, forming a dark epithecium from above. Asci 220$245 \times 13-18 \mu \mathrm{m}(\bar{x}=223 \times 15 \mu \mathrm{m} ; \mathrm{n}=10), 6-8$-spored, bitunicate, cylindrical, rounded at the apex, with a distinct of apical chamber. Ascospores 28-33 $\times 10-13 \mu \mathrm{m}(\bar{x}=30 \times 12 \mu \mathrm{m} ; \mathrm{n}=10)$, uni-seriate overlapping, ellipsoidal to fusiform, slightly rounded at both ends, 1-3-septate, slightly constricted at the central septa, reddish-brown to brown. Asexual morph: Diplodia- and Aposphaeria-like (Kutorga and Hawksworth 1997).

Material examined: BRAZIL, Matto Grosso, Morro Grande, 20 December 1893, Gust. A:n Malme 484, determined by F. Petrak 1951 (S F113846); also see Table 3.

Notes: Although Samuels \& Müller (1979) placed $R$. brasiliense in synonymy with $R$. rufulum, there was a discrepancy in spore size with the former having significantly wider asci and larger ascospores (Kutorga \& Hawksworth 1997). In our collections of $R$. brasiliense from Thailand there were also differences in spores size (Table 3). Molecular data is therefore needed for several varied collections of this species to establish if it comprises one or several taxa. For this reason we have followed Index Fungorum (2014) and have not treated $R$. brasiliense as a synonym of $R$. rufulum. 

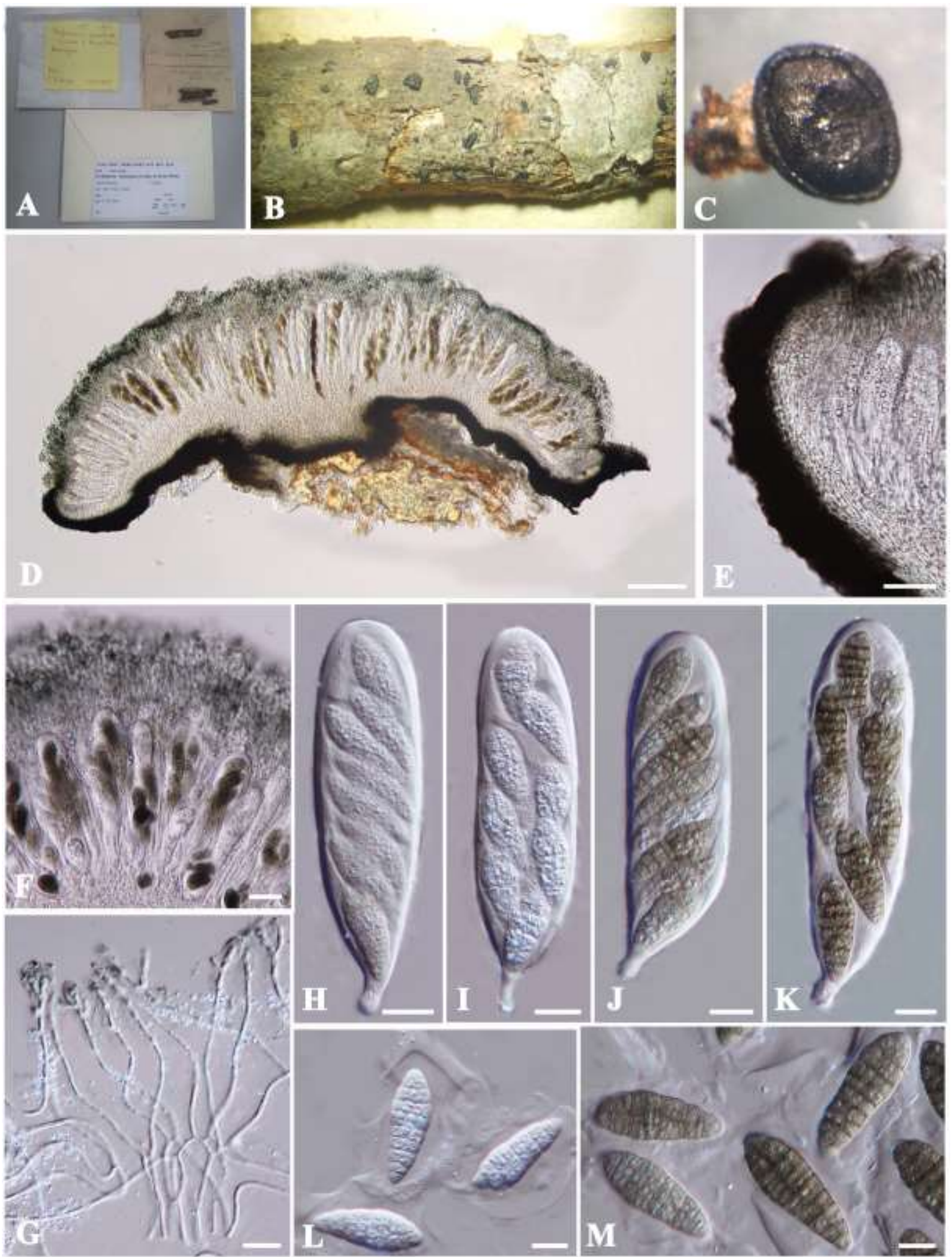

Fig. 16 - Tryblidaria fenestrata (K(M) 32624, lectotype). (A) Herbarium package and herbarium specimen. (B, C) Black apothecia on host surface and the single ascomata. (D) Hand section of apothecia. (E) Peridium layer with radiating cells. (F) Black epithecium formed over asci. (G) Branched anastomosing pseudoparaphyses. (H-K) Young and mature bitunicate asci. (L) Hyaline muriform ascospores when young. (M) Brown mature spores with mucilaginous sheath. Scale bars: $D=150 \mu \mathrm{m}, E, F=30 \mu \mathrm{m}, G=7 \mu \mathrm{m}, H-K=15 \mu \mathrm{m}, L, M=10 \mu \mathrm{m}$. 

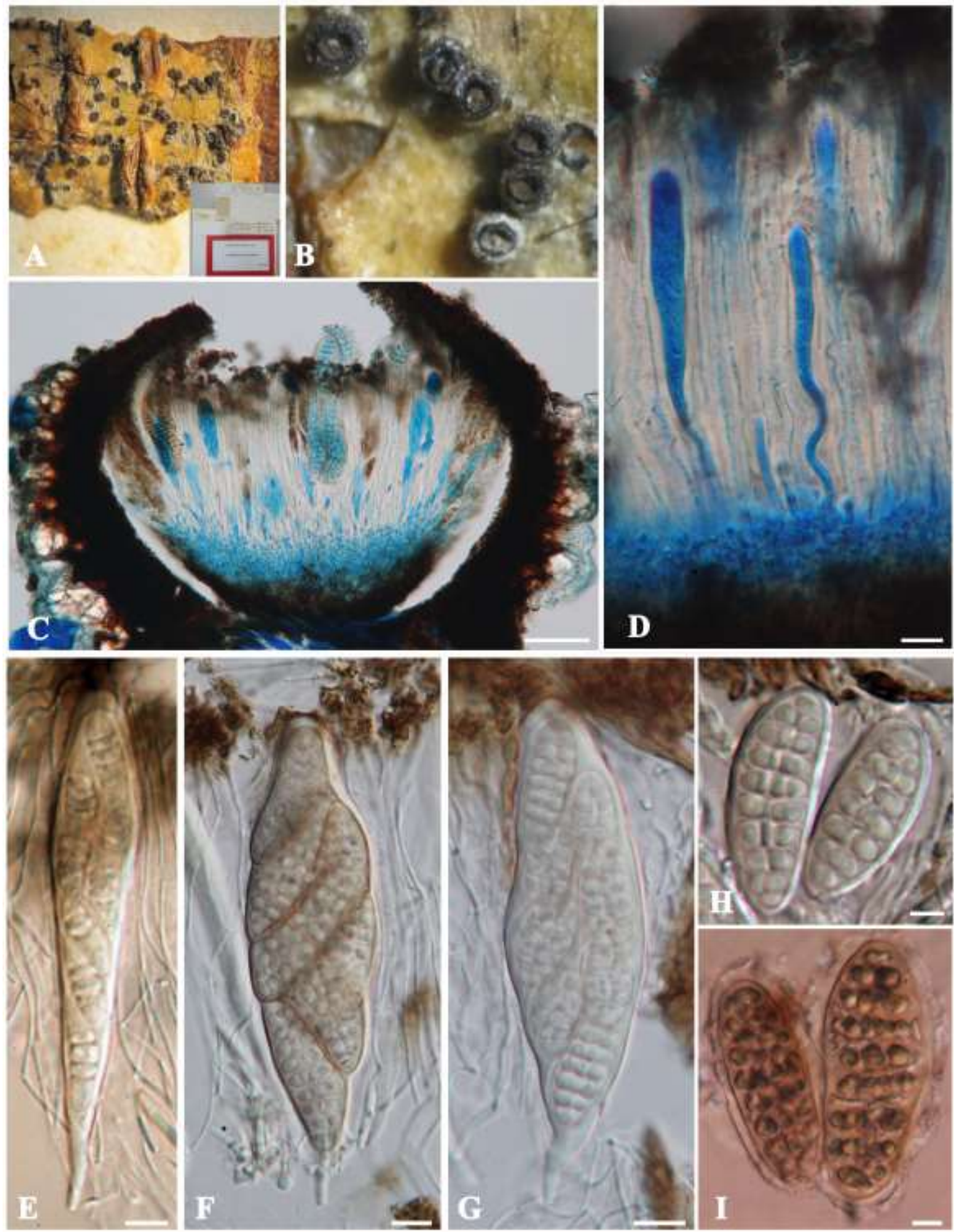

Fig. 17 - Tryblidaria breutelii (S: F61102, holotype). (A) Herbarium package with herbarium specimen. (B) Black apothecia on host tissue. (C) Vertical section of apothecium. (D) Pseudoparaphyses in Cotton blue reagent. (E) Young asci. (F-G) Mature asci with 8-spored. (H) Muriform ascospores. (I) Ascospore with sheath stained in India ink. Scale bars: $C=50 \mu \mathrm{m}, D-G=$ $10 \mu \mathrm{m}, H-I=5 \mu \mathrm{m}$.

Pseudoparodia Theiss. \& Syd., Annls mycol. 15 (1-2): 1917

Facesoffungi number: FoF 00377

Notes: Pseudoparodia was established by Petrak (1947) and assembled in Venturiaceae and transferred to Stigmateaceae by von Arx \& Müller (1975). Zhang \& Hyde (2009) reported that they 

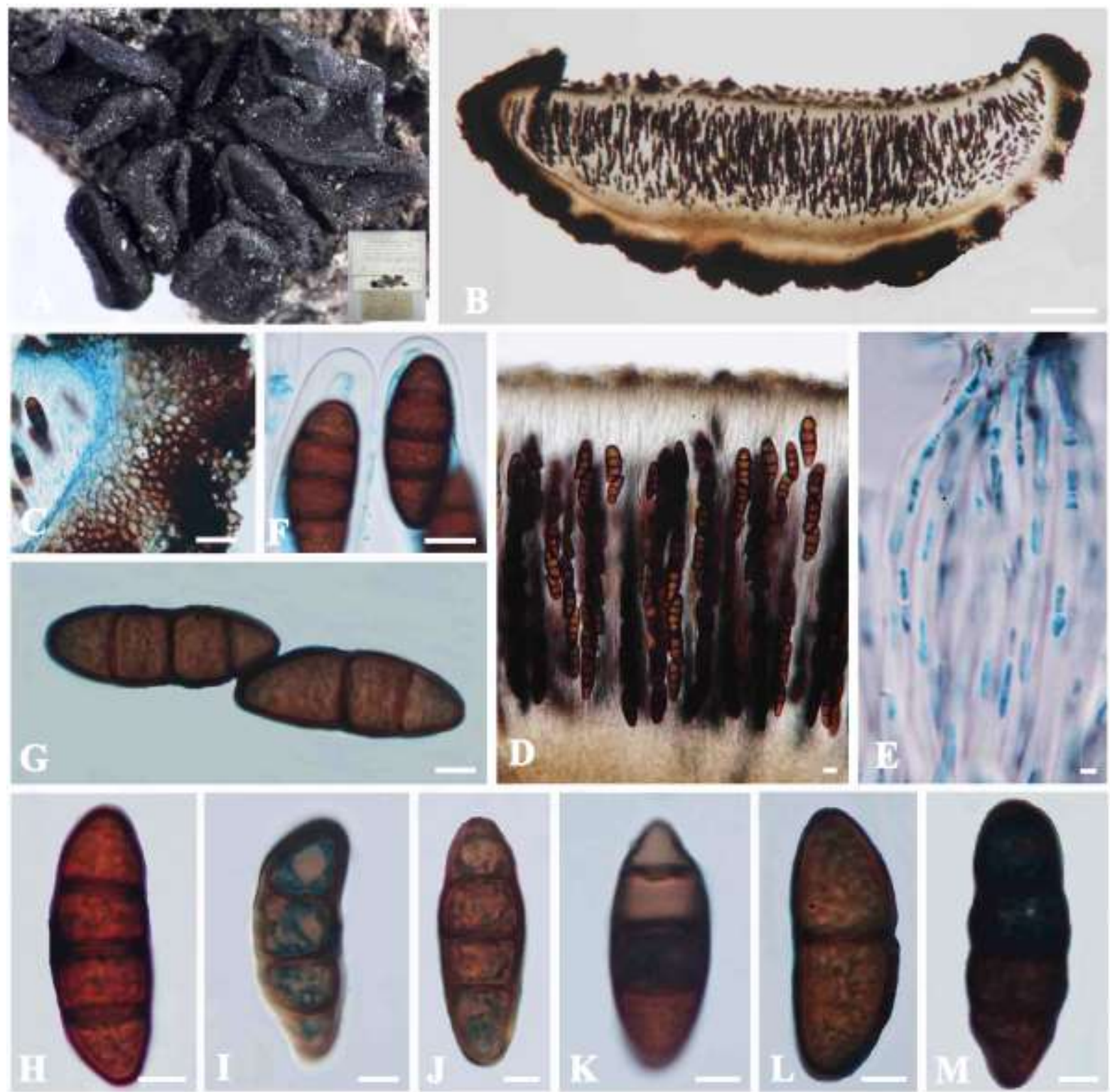

Fig. 18 - Rhytidhysteron brasiliense (S F113846). (A) Small group of apothecia on specimen. (B) Vertical section of apothecia. (C) Peridium of textura angularis. (D) Arrangement of asci and ascospores. (E) Paraphysoids with septa (stained in cotton blue). (F) Apical ocular chamber stained in cotton blue. (G-M) Ascospores. Scale bars: $B=200 \mu \mathrm{m}, C=30 \mu \mathrm{m}, D, F=10 \mu \mathrm{m}, E=2 \mu \mathrm{m}$, $G-M=5 \mu \mathrm{m}$.

found apothecia which were superficial and swollen, and dense pseudoparaphyses forming epithecium above the asci. These characters are quite different from those in the family Venturiaceae while similar to Patellariaceae. Therefore, Pseudoparodia was transferred to Patellariaceae which was followed by Lumbsch \& Huhndorf (2010) and Index Fungorum (2014).

In this study, we re-examined the holotype of Pseudoparodia and found that the ascomata are perithecioid, globose and black with bristles attached to host surface. These characters are distinguishable from main characters of Patellariaceae but without molecular data support. Therefore, we suggest to exclude Pseudoparodia from Patellariaceae and place the genus in Dothideomycetes genera incertae sedis. (1947)

Type species: Pseudoparodia pseudopeziza (Pat.) Theiss. \& Syd., Sydowia 1(4-6): 169

$\equiv$ Parodiella pseudopeziza Pat. 1895, Saccardo's Syll. fung. 24: 1144.

Fig. 19

Facesoffungi number: FoF00378 

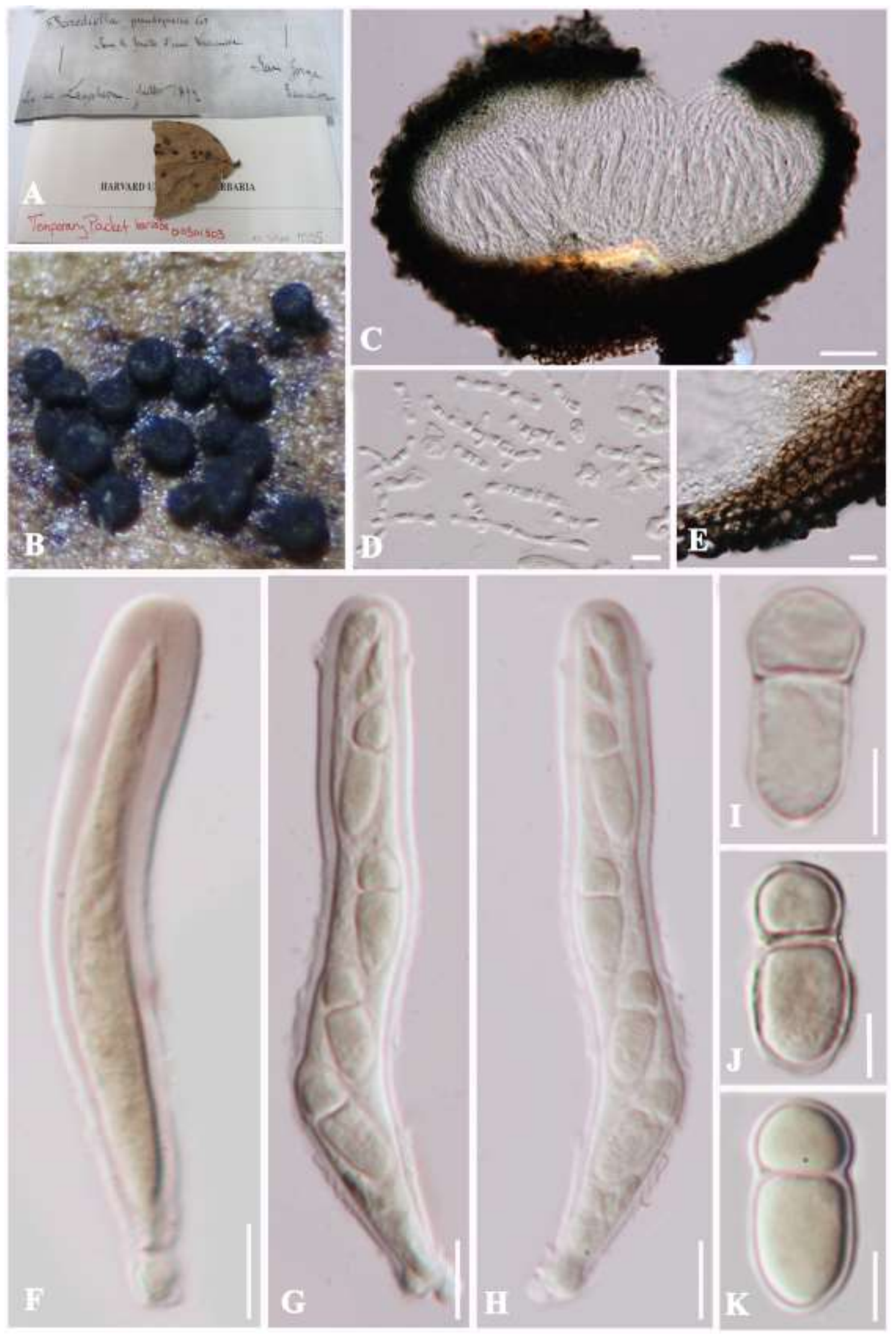

Fig. 19 - Pseudoparodia pseudopeziza (FH 7735, holotype). (A) Herbarium specimen. (B) Fruiting body on host tissue. (C) Vertical section on ascoma. (D) Peridium of textura angularis. (E) Pseudoparaphyses. (F) Young asci stained in Melzer's reagent. $(\mathrm{G}-\mathrm{H})$ Bitunicate asci with 4 spores. (I-K) Ascospores with a septate. Scale bars: $C=50 \mu \mathrm{m}, D, E-G=10 \mu \mathrm{m}, H=7 \mu \mathrm{m}, I-K=$ $5 \mu \mathrm{m}$. 
Saprobic on leaves of Vaccinium sp. in terrestrial habitats. Sexual morph: Ascomata 180-190 $\mu \mathrm{m}$ diam., perithecial, in small aggregations, superficial with bristles, brittle, spherical, globose, black, in 5\% $\mathrm{KOH}$ slightly turning to blue-black. Exciple 25-45 $\mu \mathrm{m}$ wide, thick and dense, composed of textura angularis, with outer layer comprising of black pseudoparenchyma cells, with thin, inner layer of brown cell of textura angularis. Hamathecium composed of $2-3 \mu \mathrm{m}$ wide $(\bar{x}=$ $3 \mu \mathrm{m} ; \mathrm{n}=10)$, cylindrical, to filliform, septate, unbranched, hyaline, pseudoparaphyses, with filaments slightly wide and swollen at the apex. Asci 70-100 $\times 9-11 \mu \mathrm{m}(\bar{x}=90 \times 10 \mu \mathrm{m} ; \mathrm{n}=10)$. 4-8-spored, bitunicate, cylindrical, slightly curved, short-pedicellate. Ascospores 14-17 $\times 5-9 \mu \mathrm{m}$ $(\bar{x}=16 \times 7 \mu \mathrm{m} ; \mathrm{n}=10)$, uni-seriate overlapping, ellipsoid to oblong, rounded at the ends, with upper cell short and rounded, narrow and oblong at the lower part, asymmetrically 1-transverse septate, constricted at the septa, pale brown, smooth-walled. Asexual morph: Unknown.

Material examined: ECUADOR, San Jorge, on leaves of Vaccinium sp. (Ericaceae), July 1892, Lagerh. (FH 7735, holotype).

\section{Arthoniomycetes, Melaspileaceae}

Banhegyia L. Zeller \& Tóth, Sydowia 14: 326 (1960)

Facesoffungi number: FoF00601

Notes: Banhegyia was described by Zeller and Tóth (1960), with B. setispora Zeller \& Tóth as the type species and placed in Lecanorales. Müller and von Arx (1962) transferred B. setispora to Patellariaceae. This idea was followed by Kohlmeyer (1967), von Arx and Müller (1975) and Greuter et al. (1993) because of the apothecia-like ascomata, bitunicate asci and epithecium formed from pseudoparaphyses. Eriksson and Hawksworth (1993) and Hawksworth et al. (1995) did not agree with these authors and placed this genus in Ascomycetes genera incertae sedis. Kutorga and Hawksworth (1997) and Jones et al. (2009), however, moved Banhegyia back to Patellariaceae.

Type species: Banhegyia setispora Sydowia 14: 327 (1960)

Facesoffungi number: FoF 00602

Fig. 20

Saprobic on Juniperus communis in terrestrial and marine habitats. Sexual state: Ascomata 267$339 \times 103-130 \mu \mathrm{m}$, apothecial, superficial, solitary, scattered, closed when young, opening when mature, exposing a roughened layer at the center, subglobose to disc-like, leathery, black. Exciple 15-39 $\mu \mathrm{m}$ wide, comprising an outer layer of dark brown to black, pseudoparenchymatous cells and an inner wall of relatively thin-walled cells of textura angularis. Hamathecium of 1-2 $\mu \mathrm{m}$ wide, dense, hyaline, septate, unbranched pseudoparaphyses fusing at the apex to form the pale thin epithecium. Asci $25-40 \times 22-30 \mu \mathrm{m}(\bar{x}=36 \times 25 \mu \mathrm{m} ; \mathrm{n}=10), 8$-spored, bitunicate, subglobose to obovoid, pedicel small, apically broadly rounded with a wide hyaline region, with an ocular chamber. Ascospores $10-22 \times 4-10 \mu \mathrm{m}(\bar{x}=19 \times 9 \mu \mathrm{m} ; \mathrm{n}=10)$, irregularly arranged, obovoid to ellipsoidal, upper cell usually larger than the lower cell, rounded at the ends, hyaline, becoming brown when old, 1-septate, constricted at the septa, with hyaline of bristle-like, appendages at the apex. Asexual state: Unkown.

Material examined: HUNGARY, in Beech Mountain, on Juniperus communis L. (Cupressaceae), 13 July 1959, Zeller and Tóth (BP 2835, holotype).

Celidium proximellum had been reported from Russia on Juniperus communis L. in an earlier publication by Naoumoff $(1914,1915)$. Kohlmeyer (1967) synonymized Celidium proximellum and Banhegyia setispora under B. uralensis. Kohlmeyer \& Kohlmeyer (1979) reinstated the name to Banhegyia setispora with Celidium proximellum listed as a synonym and Banhegyia uralensis being a nomenclaturally superfluous combination. Currently, there are two species listed in Banhegyia in Index Fungorum (2014), viz. B. setispora and B. uralensis.

Zeller \& Tóth (1960) while describing Banhegyia, reported ascospores having bristles at both ends, which disappear at maturity. This character was accepted and used as typical character by later workers (Kohlmeyer \& Kohlmeyer 1979, Kutorga \& Hawksworth 1997, Jones et al. 2009). However, only one appendage was observed at the ascospore apex in this study. It would be 

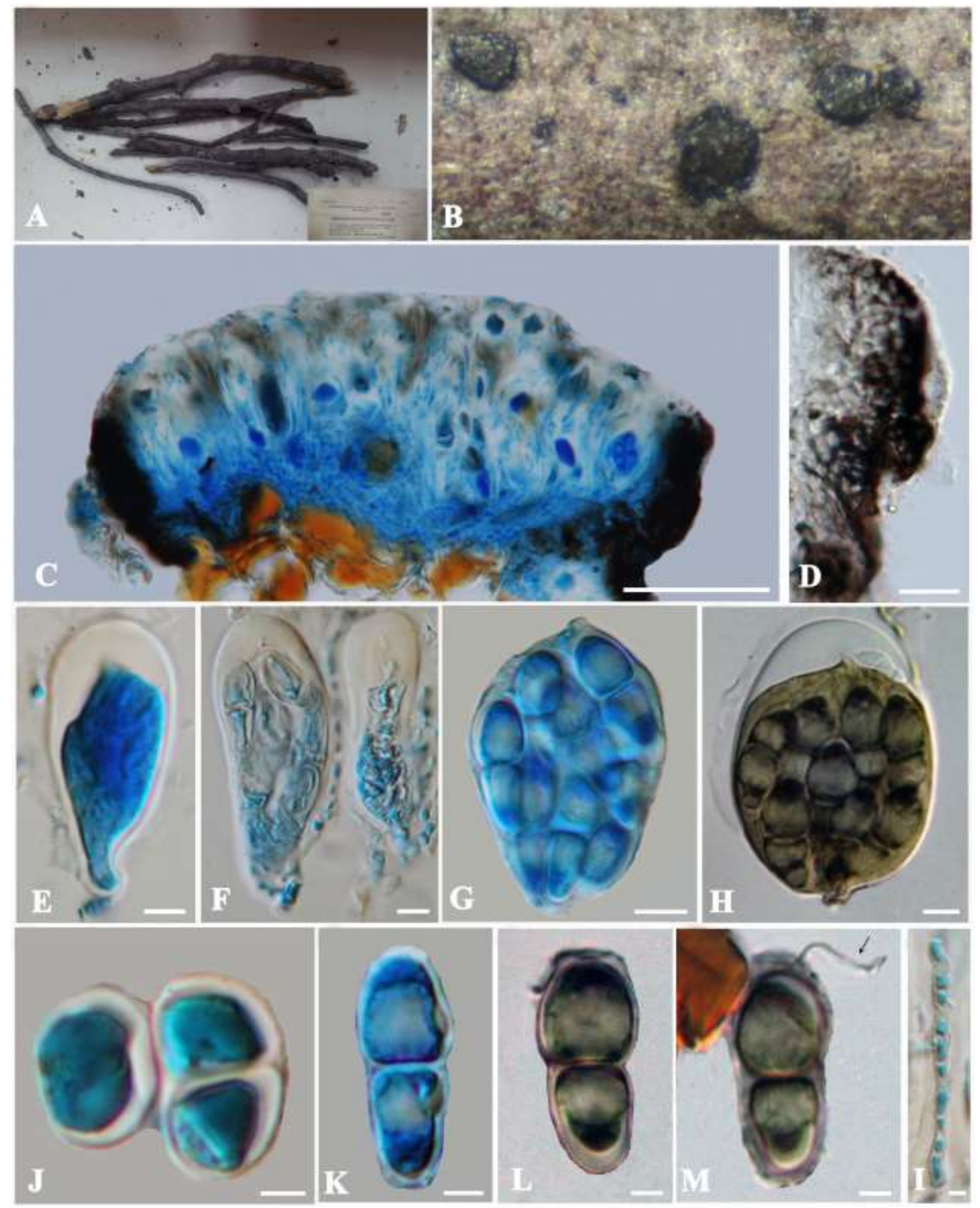

Fig. 20 - Banhegyia setispora (BP 2835, holotype). (A) Herbarium specimen. (B) Apothecia on host tissue. (C) Hand section of apothecium. (D) Peridium of textura angularis. (E, F) Young bitunicate asci. (G, H) Mature asci with 8-spored. (I) Hamathecium. (J-L) Ascospores. (M) Ascospore with polar bristles (arrowed). Scale bars: $C=50 \mu \mathrm{m}, D=10 \mu \mathrm{m}, E-H=15 \mu \mathrm{m}, I=2$ $\mu \mathrm{m}, J-N=3 \mu \mathrm{m}$.

interesting to collect more samples of this taxon to establish if the marine and mountain species are conspecific. 
Although this genus has been well-studied morphologically, there is no molecular data on its species and its familial affinity is unclear. Sanderson et al. (2009) however, synonymized Banhegyia with Mycomelaspilea (Melaspileaceae, Arthoniomycetes). This was based on morphological characters especially ascospores with bristles-like appendages, which are similar to Melaspilea bagliettoana Zahlbr. Jones et al. (2009) however, reported that Banhegyia lacked molecular information and included Banhegyia in Patellariaceae (Lumbsch \& Huhndorf, 2010). We have examined type material of Banhegyia setispora. The ascomata are apothecial and asci clearly bitunicate and typical of Patellariaceae. This species and genus therefore needs recollecting and subjecting to molecular analysis to establish its natural classification.

\section{Acknowledgements}

This study was financially supported by Thailand Research Fund (BRG5280002). We are thankful to various Herbaria for lending herbarium material for examination.

\section{References}

Almeida DAC, Gusmão LFP, Miller AN. 2014 - Brazilian Semi-Arid Ascomycetes I: new and interesting records of hysteriaceous ascomycetes. Mycosphere 5, 379-391.

Aptroot A, Van Iperen A. 1998 - New ascomycete records from Papua New Guinea. Nova Hedwigia 67, 481-497.

Auerswald B. 1866 - Baggea Awd. nov. gen. Hysteriacearum. Hedwigia 5, 1-1.

Barr ME. 1987 - Prodromus to Class Loculoascomycetes. 168 pp. Amherst, Massachusetts; University of Massachusetts.

Boehm EWA, Mugamabi GK, Miller AN, Hundrof SM, Marincowitz S, Spatafora JW, Schoch CL. 2009a -A molecular phylogenetic reappraisal of the Hysteriaceae, Mytilinidiaceae and Gloniaceae (Pleosporomycetidae, Dothideomycetes) with keys to world species. Studies in Mycology 64, 49-83.

Boehm EWA, Schoch CL, Spatafora JW. 2009b - On the evoluation of the Hysteriaceae and Mytilinidiaceae (Pleosporomycetidae, Dothideomyceetes, Ascomycota) using fore nuclear genes. Mycological Research 113, 461-479.

Bonar L. 1942 - Studies on some California fungi II. Mycologia 34, 180-192.

Boonmee S, Rossman AY, Liu JK, Li WJ, Dai DQ, Bhat DJ, Jones EBG, McKenzie EHC, Xu JC, Hyde KD. 2014 -Tubeufiales, ord. nov., integrating sexual and asexual generic names. Fungal Diversity 68, 239-298.

Butler ET. 1940 - Studies in the Patellariaceae. Mycologia 32, 791-823.

Clements FE, Shear CL. 1931 - The genera of fungi. Wilson, New York.

Corda ACI. 1838 - Icones Fungorum hucusque Cognitorum 2: i-viii, 1-43. Czechoslovakia, Prague; J.G. Calve [Fridericum Ehrlich].

Dennis RWG. 1954 - Some inoperculate discomycetes of tropical America. Kew Bulletin 2, 289348.

Dennis RWG. 1964 - The fungi of the Isle of Rhum. Kew Bulletin 19, 77-127.

Dennis RWG. 1978 - British Ascomycetes. Lubrecht \& Cramer, Vaduz.

De Notaris GE. 1867 - Nouve reclute per la Pirenomicetologia Italica. Commentario dello Societá Crittogamological Italiana 2, 477-492.

Erikson OE. 1982 - Outline of the Ascomycetes. Systema 12, 1-37.

Erikson OE. 2006 - Outline of Ascomycota. Myconet 12, 1-88.

Erikson OE, Hawksworth DL. 1993 - Outline of the ascomycets. Systema Ascomycetum 12, 51257.

Greuter W, Brummitt RK, Farr E, Kilian N, Kirk PM, Silva PC. 1993 - Names in current use for extant plant genera. Regnum Vegetabile 129, 1-1464.

Hafellner J. 1979 - Karschia revision einer Sammelattung an der Grenze von lichenisienlen und nichtlichenisierten Ascomyceten. Beihefte zur Nova Hedwigia 62, 1-188. 
Hawksworth DL, Kirk PM, Sutton BC, Pegler DN. 1995 - Ainsworth \& Bisby's Dictionary of the Fungi, eight ed. CAB International, Wallingford, UK, pp. 1-616.

Hongsanan S, Li YM, Liu JK, Hofmann T, Piepenbring M, Bhat DJ, Boonmee S, Doliom M, Singtripop C, Tian Q, Mapook A, Zeng X, Xu J, Wu XH, Hyde KD. 2014 - Revision of Asterinales. Fungal Diversity 68, 1-68.

Hyde KD, Jones EBG, Liu JK, Ariyawansa H, Boehm E, Boonmee S, Braun U, Chomnunti P, Crous PW, Dai DQ, Diederich P, Dissanayake A, Doilom M, Doveri F, Hongsanan S, Jayawardena R, Lawrey JD, Li YM, Liu YX, Lücking R, Monkai J, Muggia L, Nelsen MP, Pang KL, Phookamsak R, Senanayake IC, Shearer CA, Suetrong S, Tanaka K, Thambugala KM, Wijayawardene NN, Wikee S, Wu HX, Zhang Y, Aguirre-Hudson B, Alias AS, Aptroot A, Bahkali AH, Bezerra JL, Bhat DJ, Camporesi E, Chukeatirote E, Gueidan C, Hawksworth DL, Hirayama K, Hoog SD, Kang JC, Knudsen K, Li WJ, Li XH, Liu ZY, Mapook A, McKenzie EHC, Miller AN, Mortimer PE, Phillips AJL, Raja HA, Scheuer C, Schumm F, Taylor JE, Tian Q, Tibpromma S, Wanasinghe DN, Wang Y, Xu JC, Yacharoen S, Yan JY, Zhang M. 2013 - Families of Dothideomycetes. Fungal Diversity 63, 1-313.

Hyde KD, Nilsson RH, Alias SA, Ariyawansa HA, Blair JE, Cai L, de Cock AWAM, Dissanayake AJ, Glockling SL, Goonasekara ID, Gorczak M, Hahn M, Jayawardena RS, van Kan JAL, Laurence MH, Lévesque CA, Li X, Liu JK, Maharachchikumbura SSN, Manamgoda DS, Martin FN, McKenzie EHC, McTaggart AR, Mortimer PE, Nair PVR, Pawłowska J, Rintoul TL, Shivas RG, Spies CFJ, Summerell BA, Taylor PWJ, Terhem RB, Udayanga D, Vaghefi N, Walther G, Wilk M, Wrzosek M, Xu JC, Yan JY, Zhou N. 2014 - One stop shop: backbones trees for important phyto-pathogenic 5 genera: I (2014). Fungal Diversity 67, 21-125.

Index Fungorum. 2014 http://www.indexfungorum.org/names/NamesRecord.asp?RecordID=237092.

Jones EBG, Sakayaroj J, Suetrong S, Somrithipol S, Pang KL. 2009 - Classification of marine Ascomycota, anamorphic taxa and Basidiomycota. Fungal Diversity 35, 1-187.

Kazhieva NT. 1974 - Patellaria schwarzmanniana Kazhieva sp. nova. Botanicheskie Materialy Gerbariya Instituta Botaniki Akademii Nauk Kazakhskoi SSR 8, 93-97.

Kohlmeyer J. 1967 - Intertidal and phycophilous fungi from Tenerife (Canary Islands). Transactions of the British Mycological Society 50, 137-147.

Kohlmeyer J, Kohlmeyer E. 1979 - Marine Mycology, The higher fungi. Academic Press, London, $1-690$.

Korf RP, Zhuang WY. 1987 - On the genus Pithyella and its later synonym, Helotiopsis (Leotiaceae). Mycotaxon 29, 1-10.

Kravtzev KV. 1955 - Trudy Instituta Botaniki Akademii Sciences Kazakhskoi SSR 2, p. 171.

Kutorga E, Hawksworth DL. 1997 - A re-assessment of the genera referred to the family Patellariaceae (Ascomycota). Systema Ascomycetum 15, 1-110.

Liu JK, Phookamsak R, Doilom M, Wiki S, Mei LY, Ariyawansha H, Boonmee S, Chomnunti P, Dai DQ, Bhat DJ, Romero AI, Xhuang WY, Monkai J, Jones EBG, Chukeatirote E, KoKo TW, Zhoa YC, Wang Y, Hyde KD. 2012 -Towards a natural classification of Botryosphaeriales. Fungal Diversity 57:149-210

Liu YX, Hyde KD, Ariyawansa HA, Li WJ, Zhou D, Yang YL, Chen YM, Liu ZY. 2013 Shiraiaceae, new family of Pleosporales (Dothideomycetes, Ascomycota). Phytotaxa 103, 51-60.

Lumbsch HT, Huhndorf SM. 2010 - Outline of Ascomycota. Myconet 14, 1-69.

Magnes M, Scheuer CH, Soderholm U. 1998 - A New variety of Baggea pachyascus (Patellariaceae, Ascomycota) from Finland. Mycotaxon 68, 321-325.

Müller E, von Arx JA. 1962 - Die Gattungen der didymosporen Pyrenomyceten. Beitr. Kryptogamenflora Schweiz 11, 21-249. 
Nannfeldt JA. 1932 - Studien über die Morphologie und Systematik der nichtlichenisierten inoperculatewn Discomyceten. Nova Acta Regiae Societatis Scientiarum Upsaliensis Series 4, 8, 1-368.

Naoumoff N. 1914 - Matériaux pour la flore mycologique de la Russie. Bulletin trimestriel de la Société mycologique de France 30, 1-384.

Naoumoff N. 1915 - Champignons de l' Oural I. Bulletin de la Societe Sciences Nat 35, 1-48.

Petrak F. 1947 - Über Gibbera Fr. und verwandte Gattungen. Sydowia 1, 169-201.

Petrak F. 1959 - Über die Gattungen Eutryblidiella (Rehm) v. Höhn. und Endotryblidium n.gen. Sydowia 13, 244-245.

Petrini O. Samuels GJ. Muller E. 1979 - Holmiella sabina (de Not) comb. nov. (syn. Eutryblidiella saina) and its Corniculariella-like anamorph an endophyte of Juniperus species. Swiss Botanical Society 89, 80-91.

Pirozynski KA, Reid J. 1966 - Studies on the Patellariaceae. I. Eutryblidiella Sabina (de Not) v. Höhn. Canadian Journal of Botany 44, 655-662.

Phookamsak R, Liu JK, McKenzie EHC, Manamgoda DS, Chatpapamon C, Ariyawansa H, Thambugala KM, Dai DQ, Camporesi E, Chukeatirote E, Wijayawardene NN, Mortimer PE, Xu JC, Hyde KD. 2014 -Revision of Phaeosphaeriaceae. Fungal Diversity 68, 159238.

Rehm H. 1890 - Ascomyceten: Hysteriaceen und Discomyceten. In: Fischer, A., Hauck, F., Limpricht, G., Luerssen, Ch., Migula, W., Rehm, H., Richter, P., Winter, G. (Eds) Dr L. Rabenhorst's Kryptogamen-Flora von Deutschland, Oesterreich und der Schweiz Zweite Auflage 1, 337-400.

Rehm H. 1896 - Ascomyceten: Hysteriaceen und Discomyceten. in: Winter, G., Rehm, H. (Eds) Dr. L. Rabenhorst's Kryptogamen-Flora von Deutschland, Oesterreich und der Schweiz, Zweite Auflage vollständig neu bearbeitet, band 1 Abtheilung 3. Leipzig, 277-1275.

Rehm H. 1904 - Revision der Gattungen Tryblidiella Sacc., Rhytidhysterium Speg., Tryblidaria

Sacc., Tryblidium Rebent., Tryblidiopsis Karst. Annales mycologici 2, 522-526.

Rehm H. 1912 - Ascomycetes novi. Annales mycologici 10, 389-397.

Ruibal C, Gueidan C, Selbmann L, Gorbushina AA, Crous PW, Groenewald JZ, Muggia L, Grube M, Isola D, Schoch CL, Staley JT, Lutzoni F, de Hoog GS. 2009 - Phylogeny of rockinhabiting fungi related to Dothideomycetes. Studies in Mycology 64, 123-133.

Saccardo PA. 1883 - Sylloge fungorum omnium hucusque cognitorum 2, 1-813.

Saccardo PA. 1889 - Sylloge fungorum omnium hucusque cognitorum 8, 1-1143.

Samuels GJ, Müller E. 1979 - Life-History Studies of Brazilian Ascomycetes. 7. Rhytidhysteron rufulum and the genus Eutryblidiella. Sydowia 31, 277-291.

Sanderson NA, Hawkswotrth DL, Aptroot A. 2009 - Melaspilea Nyl., in: Smith, C.W. et al. (Eds).The lichens of Great Britain and Ireland. British Lichen Society, 576-579.

Schoch CL, Crous PW, Groenewald J, Barres B, Boehm E, de Gruyter J, de Hoog G, Dixon LJ, Fournier J, Grube M, Gueidan C, Harada Y, Hatakeyama S, Hirayama K, Hosoya T, Hyde KD, Jones EBG, Kohlmeyer J, Lucking R, Lumbsch H, Lutzoni F, Marvanova L, Mbatchou J, Miller A, Mugambi G, Muggia L, Nelson M, Nelson P, Owensby C, Phongpaichit S, Pointing S, Pujade-Renaud V, Raja H, Rivas-Plata E, Robbertse B, Ruibal C, Sakayaroj J, Sano T, Selbmann L, Shearer C, Shirouzu T, Slippers B, Suetrong S, Tanaka K, Volkmann-Kohlmeyer B, Wood A, Woudenberg J, Yonezawa H, Zhang Y, Spatafora J. 2009 - A class wide phylogenetic assessment of Dothideomycetes. Studies in Mycology 64, 1-15.

Seaver FJ. 1951 - The North American Cup-fungi (Inopercolates Edn). Seaver, F.J. New York, 428pp.

Sherwood MA. 1980 - Taxonomic studies in the Phacidiales: the genus Coccomyces (Rhytismataceae). Occasional Papers of the Farlow Herbarium of Cryptogamic Botany 15, $1-120$. 
Sherwood MA. 1986 - New and unusual ascomycetes from the Western United States. Sydowia 38, 267-277.

Spegazzini C. 1881 - Fungi Argentini Additis Nonnullis Brasiliensibus Montevideensibusque, in: Berg, DC, Clerici EE, Silva A, Arribavzaga EL, Valle PD (Eds.), Anales de la Sociedad Clentífica Argentina. De Pablo E. Coni, Agentina, 188-189.

Suetrong S, Jones EBG. 2006 - Marine discomycetes: A review. Indian Journal of Marine Sciences 35, 291-296.

Suetrong S, Schoch CL, Spatafora JW, Kohlmeyer J, Kohlmeyer BV, Sakayaroj J, Phongpaichit S, Tanaka K, Hirayama K, Jones EBG. 2009 - Molecular systematics of the Dothideomycetes. Studies in Mycology 64, 155-173.

Tilak ST, Srinivasulu BV. 1974 - Genus Patellaria from India. Beihefte zur Nova Hedwigia 47, 459-462.

Unterseher M, Otto P, Morawetz W. 2003 - Studies of the diversity of lignicolous fungi in the canopy of a floodplain forest in Leipzig, Saxony. Boletus 26, 117-126.

Von Arx JA, Müller E. 1975 - A re-evaluation of the bitunicate Ascomycetes with keys to families and genera. Studies in Mycology 9, 1-159.

Wijayawardene NN, Hyde KD, Camporesi E, Bhat DJ, Song Y, Chukeatirote E, Wang Y, Zhang JH. 2014 - Homortomyces tamaricis sp. nov. and convergent evolution of Homortomyces and Stilbospora. Phytotaxa 176, 156-163.

Wijayawardene NN, McKenzie EHC, Hyde KD. 2012 - Towards incorporating anamorphic fungi in a natural classification-checklist and notes for 2011 Mycosphere 3, 157-228.

Zeller VFL, Tóth S. 1960 - Bánhegyia, eine neue Gattung der Lecanorales. Sydowia 14, 326-329.

Zhang Y, Hyde KD. 2009 - Transfer of Pseudoparodia pseudopeziza to Patellariaceae (Patellariales). Nova Hedwigia 88, 211-215.

Zhang Y, Fournier J. Phookamsak R, Bahkali AH, Hyde KD. 2013 - Halotthiaceae fam. nov. (Pleosporales) accommodates the new genus Phaeoseptum and several other aquatic genera. Mycologia 105, 603-609.

Zogg H, 1962 - Die Hysteriaceae s. str. und Lophiaceae unter besonderer Berücksichtigung dermitteleuropäischen Formen. Beit. Kryptogamenflora der Schweiz 11, 1-190. 